\title{
Presynaptic Inhibition by GABA Is Mediated via Two Distinct GABA Receptors with Novel Pharmacology
}

\author{
Gary Matthews, George S. Ayoub, ${ }^{a}$ and Ruth Heidelbergerb \\ Department of Neurobiology and Behavior, State University of New York, Stony Brook, New York 11794-5230
}

\begin{abstract}
Mechanisms of presynaptic inhibition were examined in giant presynaptic terminals of retinal bipolar neurons, which receive GABAergic feedback synapses from amacrine cells. Two distinct inhibitory actions of GABA are present in the terminals: a $\mathrm{GABA}_{\mathrm{A}}$-like $\mathrm{Cl}$ conductance and a $\mathrm{GABA}_{\mathrm{B}}$-like inhibition of voltage-dependent $\mathrm{Ca}$ current. Both of the receptors underlying these actions have unusual pharmacology that fits neither $\mathrm{GABA}_{A}$ nor $\mathrm{GABA}_{B}$ classifications. The GABA-activated $\mathrm{Cl}$ conductance was not blocked by the classical GABA $_{A}$ antagonist bicuculline, while the inhibition of $\mathrm{Ca}$ current was neither mimicked by the $\mathrm{GABA}_{B}$ agonist baclofen nor blocked by the $G_{A B A}$ antagonist 2-hydroxysaclofen. The "GABA" agonist cis-4-aminocrotonic acid (CACA) both activated the $\mathrm{Cl}$ conductance and inhibited $\mathrm{Ca}$ current, but the inhibition of $\mathrm{Ca}$ current was observed at much lower concentrations of CACA $(<1 \mu \mathrm{M})$ than was the activation of the $\mathrm{Cl}$ conductance $\left(K_{1 / 2}=50 \mu \mathrm{M}\right)$. Thus, by the criterion of being insensitive to both bicuculline and baclofen, both GABA receptors qualify as potential GA$B_{C}$ receptors. However, it is argued on functional grounds that the two GABA receptors coupled to $\mathrm{Cl}$ channels and to $\mathrm{Ca}$ channels are best regarded as members of the $\mathrm{GABA}_{\mathrm{A}}$ and $\mathrm{GABA}_{\mathrm{B}}$ families, respectively.
\end{abstract}

[Key words: GABA receptors, synaptic transmission, calcium current, retina, bipolar neurons, presynaptic inhibition]

Presynaptic inhibition and the modulation of transmitter release from presynaptic terminals are important processes in neural signaling. Despite this, there is little direct information about the mechanisms by which neurotransmitters affect synaptic terminals. An exception is the giant synaptic terminal of bipolar neurons from goldfish retina, which is well suited for direct patch-clamp measurements of ionic conductance and fura-2 measurements of internal calcium in single synaptic terminals (Heidelberger and Matthews, 1992). Further, the terminal receives extensive GABAergic feedback synapses from amacrine cells (Yazulla et al., 1987), and GABA has been shown to inhibit calcium influx in the terminal via activation of $\mathrm{Cl}$ conductance

\footnotetext{
Received April 6, 1993; revised June 23, 1993; accepted July 29, 1993.

This work was supported by NIH Grant EY03821. We thank Helen Scharfman and Kavita Peshori for providing controls for the efficacy of the lots of bicuculline and baclofen used in our experiments.

Correspondence should be addressed to Dr. Gary G. Matthews at the above address.

a Present address: Department of Biology, Westmont College, 955 La Paz Road, Santa Barbara, CA 93108.

b Present address: Abteilung Membranhiophysik, Max-Planck-Institut fir biophysikalische Chemie, Am Fassberg, 37077 Göttingen, Germany.

Copyright (C) 1994 Society for Neuroscience 0270-6474/94/141079-12\$05.00/0
}

and to reduce the presynaptic calcium current (Heidelberger and Matthews, 1991). Our goal in the work reported here was to investigate the pharmacology of these two actions of GABA in order to specify which GABA-receptor subtypes are involved in the two distinct types of presynaptic inhibition present in the bipolar-cell terminal. Receptors for GABA are typically divided into two classifications, $\mathrm{GABA}_{\mathrm{A}}$ and $\mathrm{GABA}_{\mathrm{B}}$, based on pharmacological criteria and on the nature of the coupling between the receptor and ion channels. $\mathrm{GABA}_{\mathrm{A}}$ receptors are ligandgated ion channels in which the GABA binding site is directly linked to a chloride channel (Schofield et al., 1987), while GA$\mathrm{BA}_{\mathrm{B}}$ receptors are coupled indirectly to potassium or calcium channels via G-proteins (Andrade et al., 1986; Holz et al., 1986). The usual pharmacological criteria are that $\mathrm{GABA}_{\mathrm{A}}$ receptors are activated by the GABA analog muscimol and blocked by the antagonists bicuculline and picrotoxin (Curtis et al., 1970), while $\mathrm{GABA}_{\mathrm{B}}$ receptors are activated by baclofen (Bowery et al., 1980) and blocked by saclofen and phaclofen (Kerr et al., 1989).

We found that GABA activates a picrotoxin-sensitive $\mathrm{Cl}$ conductance in the synaptic terminal of bipolar cells, as reported previously (Tachibana and Kaneko, 1987; Heidelberger and Matthews, 1991), but that bicuculline did not block this effect; $\mathrm{GABA}_{\mathrm{B}}$ agonists and antagonists had no effect on the $\mathrm{Cl}$ conductance. Similar bicuculline-resistant $\mathrm{GABA}_{\mathrm{A}}$ receptors have also recently been described in retinal horizontal cells (Qian and Dowling, 1993) and neonatal rat bipolar cells (Feigenspan et al., 1993). Such bicuculline- and baclofen-resistant GABA receptors have in the past been called $\mathrm{GABA}_{C}$ receptors (Johnston et al., 1975; Drew et al., 1984; Shimada et al., 1992). However, we found that the putative $\mathrm{GABA}_{C}$ agonist cis-4-aminocrotonic acid (CACA) was much less effective than the trans isomer of crotonic acid (TACA) in activating the $\mathrm{Cl}$ conductance. Because TACA is considered to be a $\mathrm{GABA}_{\mathrm{A}}$ agonist (Johnston et al., 1975), the GABA receptor coupled to $\mathrm{Cl}$ conductance in the synaptic terminal may best be regarded as a bicuculline-resistant member of the increasingly diverse $\mathrm{GABA}_{\mathrm{A}}$ family (Sigel et al., 1990; Burt and Kamatchi, 1991), rather than as distinct GABAreceptor family.

In addition to activating $\mathrm{Cl}$ conductance, GABA also inhibited calcium current in bipolar-cell synaptic terminals, and this effect also had unusual pharmacology: ncither $\mathrm{GABA}_{\mathrm{A}}$ nor GA$\mathrm{BA}_{\mathrm{B}}$ drugs were effective. This is different from previously reported inhibition of Ca current by GABA in amphibian bipolar cells (Maguire et al., 1989), where the underlying receptor had classical $\mathrm{GABA}_{\mathrm{B}}$ pharmacology. In our experiments, although $\mathrm{GABA}_{B}$ drugs were without effect, the $\mathrm{GABA}_{C}$ agonist CACA was found to be a selective agonist that mimicked the action of 

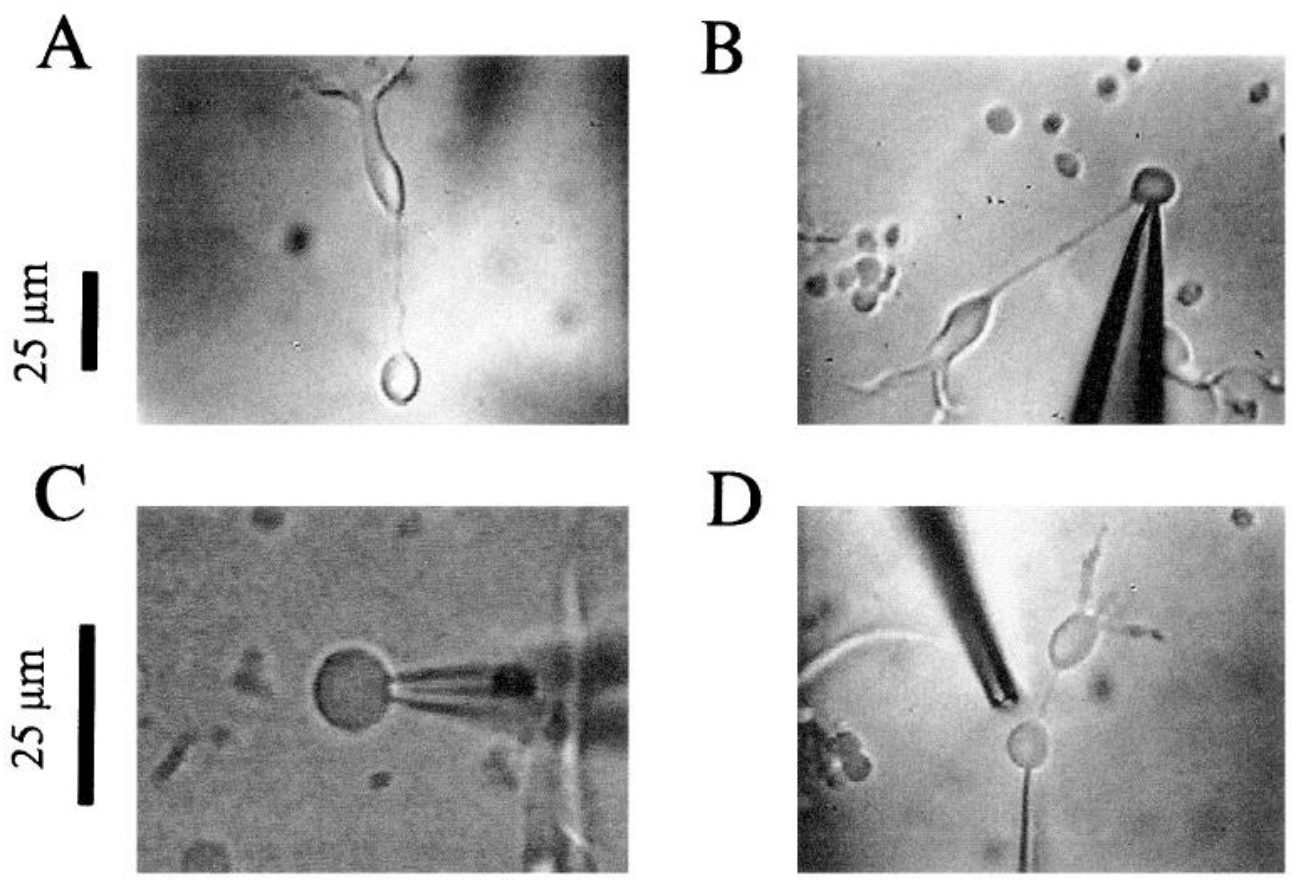

Figure 1. Examples of bipolar neurons isolated from goldfish retina. All pictures show single video frames taken during experiments, which were routinely videotaped. $A$, Typical morphology of an isolated bipolar neuron identified as type Mbl. The cell had stout dendrites, a large flask-shaped soma, and a single bulbous synaptic terminal (average diameter, $10 \mu \mathrm{m}$; range, $8-14 \mu \mathrm{m}$ ). Scale bar applies to $B$ and $D$, as well. $B$, For electrical recordings, a whole-cell patch pipette was placed on the synaptic terminal. $C$, A recording from an isolated terminal. In some experiments, the terminal was isolated by severing the axon or by destroying the cell body. The stump of the axon retracted and was absorbed into the terminal, giving the spherical terminal shown in the picture. In this example, the cell body disintegrated and was no longer visible, which was a common occurrence. $D$, Drugs were applied to the synaptic terminal by local superfusion using a pressure-application pipette. Two or three separate application pipettes (not shown), containing different drugs or combinations of drugs, were available. Gentle pressure, controlled by micrometer-driven syringes, was continuously applied to the application pipettes, which were raised out of the bath solution and lowered to the cells to apply drugs.

GABA on Ca current at concentrations substantially below those required for activation of $\mathrm{Cl}$ conductance by $\mathrm{CACA}$. The effect of CACA on Ca current required GTP, and it is therefore likely that this receptor is a baclofen-insensitive member of the GA$\mathrm{BA}_{\mathrm{B}}$ family, about which there is no molecular information comparable to that available for $\mathrm{GABA}_{\mathrm{A}}$ receptors.

\section{Materials and Methods}

Cell preparation and electrical recording. Single bipolar neurons were acutely isolated from goldfish retina after enzymatic digestion as detailed by Heidelberger and Matthews (1992). Recordings were typically made within $0.5-4 \mathrm{hr}$ of dissociation. Based on their characteristic morphology (see Fig. $1 A$ ), especially the large bulbous synaptic terminal $(8-12 \mu \mathrm{m}$ in diameter), cells were identified as type Mb1 bipolar neurons (Ishida et al., 1980; Yazulla et al., 1987). Examples of isolated neurons used in experiments are shown in Figure 1. Whole-cell patch-clamp pipettes were placed on the synaptic terminal (Fig. $1 B$ ). In some experiments, isolated synaptic terminals were prepared either by severing the axon or by destroying the cell body with the patch pipette used to record from the preceding cell. A recording pipette placed on an isolated terminal is shown in Figure $1 C$. Patch pipettes had resistances of 5-9 M $\Omega$, typically giving access resistances of $12-20 \mathrm{M} \Omega$.

Solutions. The external Ringer's solution contained $120 \mathrm{~mm} \mathrm{NaCl}$, $2.6 \mathrm{~mm} \mathrm{KCl}, 1.0 \mathrm{~mm} \mathrm{MgCl}_{2}, 2.5 \mathrm{~mm} \mathrm{CaCl}_{2}, 10 \mathrm{~mm}$ HEPES, and 10 $\mathrm{mm}$ glucose, $\mathrm{pH}$ 7.3. Drugs were dissolved in the external solution and applied by local superfusion, typically to the synaptic terminal only, via a pressure-application pipette (Fig. $1 D$ ). The high-Cl pipette solution contained $120 \mathrm{~mm} \mathrm{CsCl}, 10 \mathrm{~mm}$ tetraethylammonium (TEA) $\mathrm{Cl}, 5$ or $10 \mathrm{~mm} \mathrm{Cs}_{2}$ EGTA, $10 \mathrm{~mm}$ HEPES, $2 \mathrm{~mm} \mathrm{MgCl}_{2}, 2 \mathrm{~mm} \mathrm{Na} \mathrm{m}_{2} \mathrm{ATP}$, and $0.3 \mathrm{~mm}$ GTP $(\mathrm{pH}=7.2$ ). In the low-Cl pipette solution, $\mathrm{CsCl}$ was replaced with Cs-gluconate. For experiments in which it was not desired to block potassium channels, $\mathrm{K}$-gluconate replaced both $\mathrm{CsCl}$ and TEA-Cl.

Fura- 2 measurements. To record $[\mathrm{Ca}]_{i}$ in synaptic terminals, isolated bipolar cells were loaded with fura-2 acetoxymethyl ester (fura-2AM) by incubation for $10-30 \mathrm{~min}$ in $1 \mu_{\mathrm{M}}$ fura-2AM in Ringer's solution containing $0.2 \mathrm{~mm} \mathrm{Ca}$. Cells were then washed thoroughly in fura-free Ringer's and stored for 20-30 min before experiments started. For experiments, the Ringer's solution typically contained $90 \mathrm{~mm} \mathrm{NaCl}+30$ $\mathrm{mm}$ choline- $\mathrm{Cl}$ instead of $120 \mathrm{~mm} \mathrm{NaCl}$; to depolarize cells and activate $\mathrm{Ca}$ influx, the choline was replaced by $\mathrm{KCl}$, bringing total $[\mathrm{K}]_{o}$ to 32.6 mM. The photomultiplier system for measuring emitted light was detailed in Heidelberger and Matthews (1992). Light was collected from a $30-\mu$ m-diameter aperture in the field of view, and with the synaptic terminal in the center of the aperture, no light was measured from the cell body and dendrites of an intact bipolar neuron.

\section{Results}

A large majority of the feedback synapses made by amacrine cells directly onto the synaptic terminals of bipolar neurons are GABAergic (Yazulla, 1986). We find that GABA has two distinct actions on the bipolar-cell synaptic terminal, which will be discussed in separate sections in Results. First, we will describe the properties of the chloride conductance activated in the terminal via GABA receptors that differ from classical GA$\mathrm{BA}_{\mathrm{A}}$ and $\mathrm{GABA}_{\mathrm{B}}$ receptors. Then, in the second section, we will describe the inhibition of calcium current in the terminal by $\mathrm{GABA}$ and the putative $\mathrm{GABA}_{\mathrm{C}}$ agonist CACA.

\section{GABA-activated chloride conductance in synaptic terminals}

The effect of GABA on membrane current was examined using whole-cell patch-clamp recording either from intact isolated bipolar neurons or from single isolated synaptic terminals (Fig. 1). Application of GABA to the synaptic terminal of an isolated bipolar neuron produced a large conductance increase. As shown 


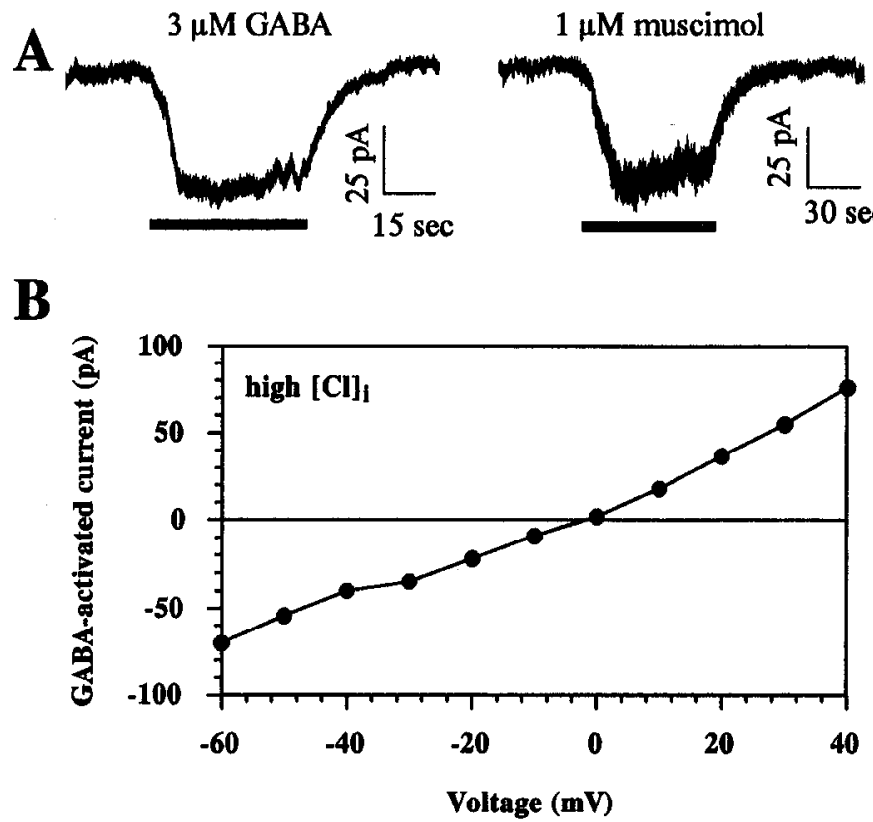

C

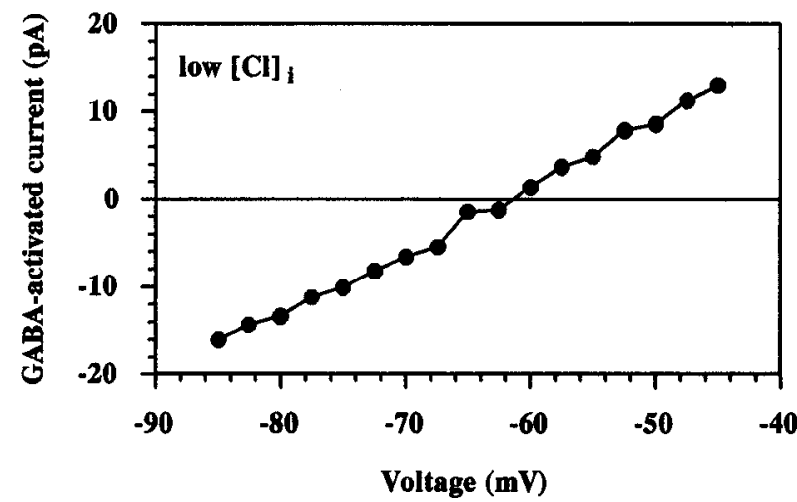

Figure 2. Activation of chloride conductance by GABA and muscimol. $A$, Examples of membrane currents elicited by local superfusion of the synaptic terminal of an isolated bipolar neuron with GABA (left) or muscimol (right). Responses are from two different cells. The holding potential was $-60 \mathrm{mV}$, and recording pipette contained $\mathrm{CsCl} / \mathrm{TEA}-\mathrm{Cl}$ solution. The bars below each trace show the approximate timing of drug applications. $B$, Reversal potential of GABA-activated current with pipette solution containing high $[\mathrm{Cl}](\mathrm{CsCl} / \mathrm{TEA}-\mathrm{Cl}$ solution). Internal $[\mathrm{Cl}]=134 \mathrm{~mm}$; external $[\mathrm{Cl}]=130 \mathrm{~mm}$. The current shown is the current in the presence of $3 \mu \mathrm{M} \mathrm{GABA}$ minus the current in the absence of GABA, and the reversal potential is near $0 \mathrm{mV} . C$, Reversal potential of GABA-activated current with pipette solution containing low $[\mathrm{Cl}]$ ( $\mathrm{CsCl}$ replaced by $\mathrm{Cs}$-gluconate; internal $[\mathrm{Cl}]=14 \mathrm{mM})$. Current is difference current activated by $1 \mu \mathrm{M}$ GABA.

in Figure $2 A$, this conductance increase was accompanied by an inward membrane current at the holding potential of $-60 \mathrm{mV}$ when the cell was dialyzed with a pipette solution containing high $[\mathrm{Cl}]$. Under these conditions, the reversal potential for the $\mathrm{GABA}$-activated current was near $0 \mathrm{mV}$ (Fig. $2 B$ ), with an average of $-0.6 \pm 3.3 \mathrm{mV}$ in seven experiments. This is as expected for a chloride current, given the approximately symmetrical distribution of $\mathrm{Cl}$ across the membrane with the high- $\mathrm{Cl}$ pipette solution. When most of the chloride in the pipette solution was replaced by gluconate, the reversal potential of the GABA-activated current was near the $-60 \mathrm{mV}$ holding potential (Fig. $2 C$ ). With the low-Cl pipette solution, the reversal potential
$\mathbf{A}$
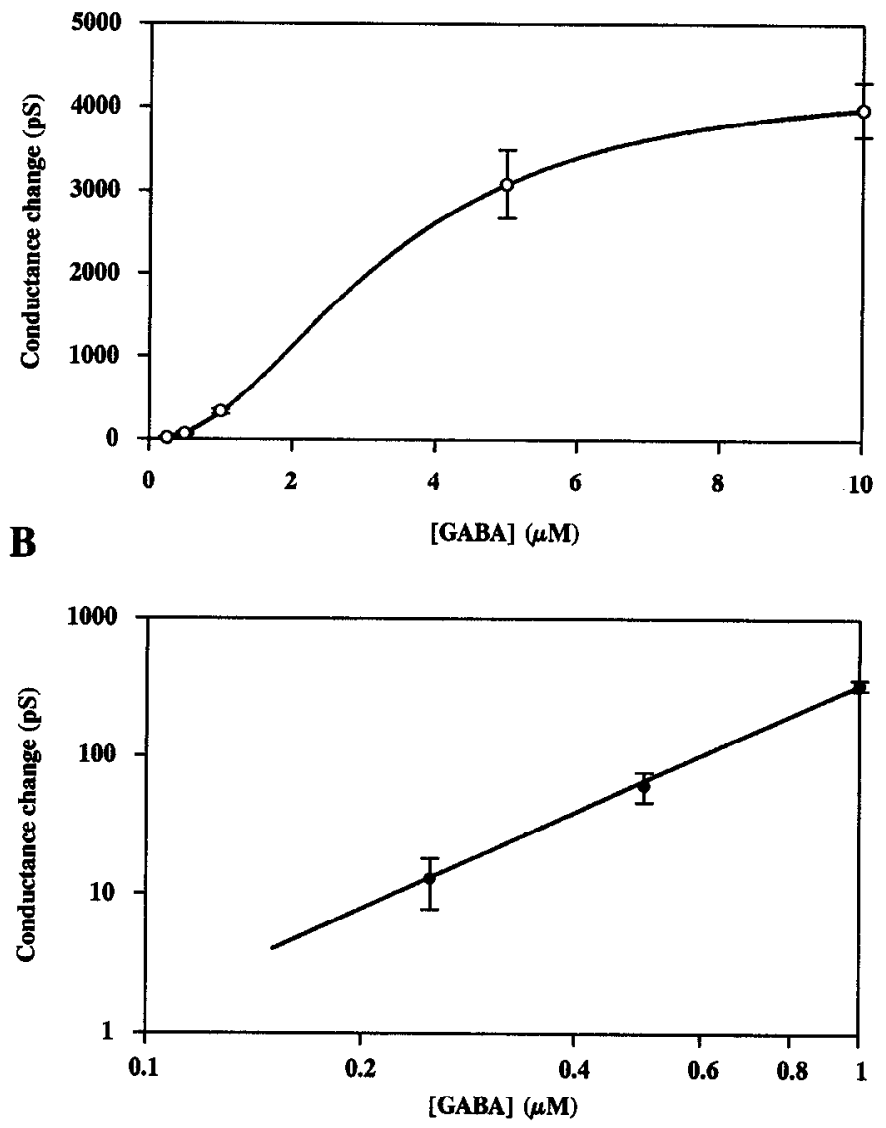

Figure 3. Dose-response relation for conductance activated by GABA in bipolar-cell synaptic terminal. $A$, Overall relation on linear coordinates. Data points are average conductance increase elicited by GABA in 4-10 individual cells. For each cell, the conductance change was determined from the slope of the current-voltage relation measured with a linear voltage ramp from -80 to $-40 \mathrm{mV}$ in the presence and absence of the indicated concentration of GABA. The solid line was fitted to the points using a least-squares criterion and was drawn according to the equation $g=g_{\max } /\left(1+\left(K_{1 / 2} /[\mathrm{GABA}]\right)^{n}\right)$, where $g_{\max }=$ $4363 \mathrm{pS}, K_{1 / 2}=3.3 \mu \mathrm{M}$, and $n=2.1$. $B$, Close view of lower three concentrations on double-logarithmic coordinates. The straight line was fitted by eye and has a slope of 2.3 .

averaged $59 \pm 1.6 \mathrm{mV}$ in 16 cells, which is close to the expected $\mathrm{Cl}$ equilibrium potential of $-56 \mathrm{mV}$ under these ionic conditions. Thus, in agreement with previous reports (Tachibana and Kaneko, 1987; Heidelberger and Matthews, 1991), GABA activated a $\mathrm{Cl}$ conductance in bipolar-cell synaptic terminals.

The GABA-activated conductance of the terminal was sensitive to relatively low concentrations of GABA, and the doseresponse relation showed a half-saturating concentration $\left(K_{1 / 2}\right)$ of approximately $3 \mu \mathrm{M}$ (Fig. $3 A$ ). This is substantially lower than the $K_{1 / 2}$ reported, for example, for brain $\mathrm{GABA}_{\mathrm{A}}$ channels expressed in oocytes $(\sim 100 \mu \mathrm{M}$; Woodward et al., 1992) and is more similar to that of retinal GABA channels expressed in oocytes ( $\sim \mu \mathrm{M}$; Shimada et al., 1992; Woodward et al., 1992). In agreement with previous studies (Bormann and Clapham, 1985; Bormann and Kettenmann, 1988), the asymptotic slope of the dose-response curve on double-logarithmic coordinates at low GABA concentrations was about 2 (Fig. $3 B$ ), suggesting that two molecules of $\mathrm{GABA}$ are required to open a channel. 
A

Figure 4. Effects of $\mathrm{GABA}_{\mathrm{A}}$ receptor blockers picrotoxin and bicuculline on $\mathrm{Cl}$ conductance activated by GABA in bipolar-cell synaptic terminals. $A$, Trace shows membrane current activated by GABA at a holding potential of -60 $\mathrm{mV}$ with and without $50 \mu \mathrm{M}$ picrotoxin. Pipcttc solution was $\mathrm{CsCl} / \mathrm{TEA}-\mathrm{Cl}$. The current-voltage curve for a different cell at rest and in the presence of GABA and GABA + picrotoxin is shown at the right. $B$, Trace shows membrane current activated by GABA at a holding potential of $-60 \mathrm{mV}$ with and without bicuculline methylchloride (bic. MC). The current-voltage curves on the right also show that bicuculline did not affect the GABA-induced conductance change. Similar results were also obtained with bicuculline and bicuculline methiodide at concentrations from 30 to $200 \mu \mathrm{M}$.

B
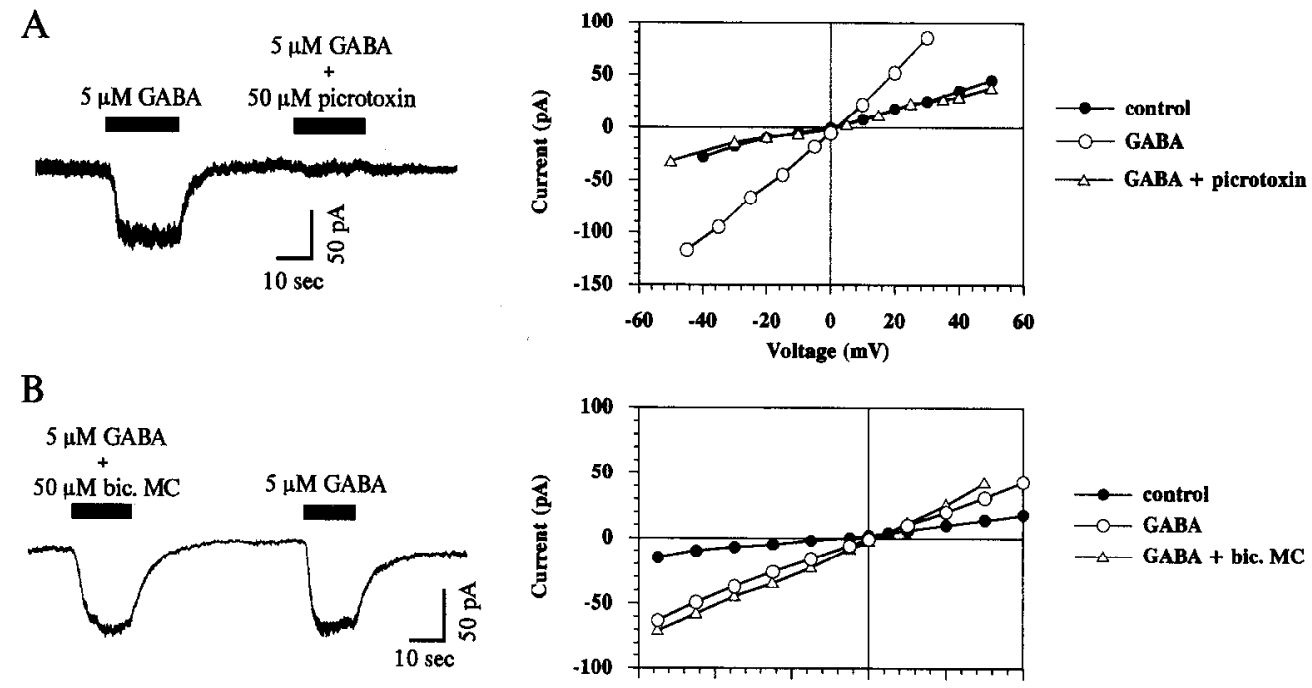

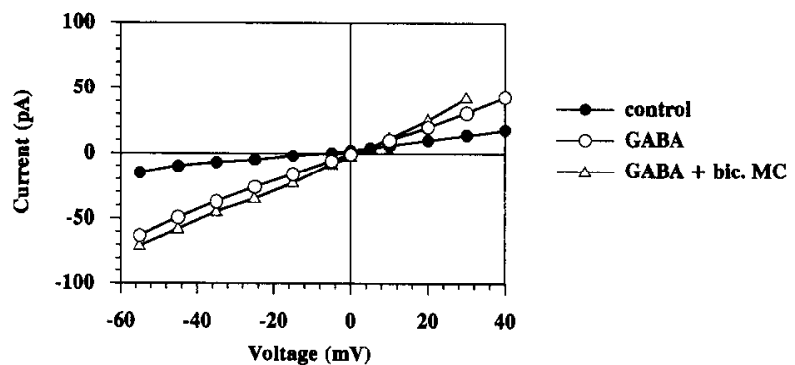

\section{Pharmacology of GABA-activated chloride conductance}

GABA receptors coupled to $\mathrm{Cl}$ channels are usually considered to represent the $\mathrm{GABA}_{\mathrm{A}}$ class of receptor/channel complex. These receptors are defined pharmacologically by activation by muscimol, blockade by picrotoxin, and blockade by bicuculline. As expected for $\mathrm{GABA}_{\mathrm{A}}$ receptors, the GABA-activated $\mathrm{Cl}$ conductance in bipolar-cell synaptic terminals was activated by muscimol (Fig. 2A), and 50-200 $\mu \mathrm{M}$ picrotoxin was able to abolish the conductance change produced by $1-5 \mu \mathrm{M}$ GABA (Fig. $4 A$ ). As shown in Figure $4 B$, however, bicuculline had little effect. This was true of bicuculline itself and of the more soluble methylchloride and methiodide derivatives. In eight cells, the response to GABA + bicuculline methylchloride was $90 \pm 5 \%$ (mean $\pm \mathrm{SEM}$ ) of the control response to GABA alone; by way of comparison, in eight other cells the response to GABA + picrotoxin was $5.5 \pm 2.8 \%$ of the response to GABA alone. The effectiveness of the bicuculline methylchloride used in these experiments was confirmed by blockade of classical $\mathrm{GABA}_{\mathrm{A}}$ responses in hippocampal slice $(\mathrm{H}$. Scharfman, personal communication) and by blockade of GABA responses from unidentified multipolar neurons (probably ganglion cells, as evidenced by the presence of fast action potentials in voltage recordings) in our preparations of dissociated retinal neurons. Thus, the GABA receptors coupled to $\mathrm{Cl}$ channels in the synaptic terminals of bipolar neurons differ from classical $\mathrm{GABA}_{A}$ receptors in being insensitive to bicuculline.

We have reported previously that GABA was a potent inhibitor of increases in $[\mathrm{Ca}]_{i}$ elicited by potassium depolarization in synaptic terminals of isolated bipolar neurons (Heidelberger and Matthews, 1991). Because this action of GABA has functionally important implications for the release of transmitter by bipolar neurons, we examined whether the effect of GABA on depolarization-induced $\mathrm{Ca}$ influx also showed unusual pharmacology like that of the $\mathrm{Cl}$ conductance. In these experiments, intact bipolar neurons were loaded with fura-2AM, and increases in $[\mathrm{Ca}]_{i}$ were elicited by elevating $[\mathrm{K}]_{o}$ to $32 \mathrm{~mm}$. As demonstrated previously (Heidelberger and Matthews, 1992), the resulting dcpolarization causes influx of external calcium into the synaptic terminal via dihydropyridine-sensitive voltage-dependent $\mathrm{Ca}$ channels. An example of the effect of GABA and muscimol on these $\mathrm{Ca}$ responses is shown in Figure $5 \mathrm{~A}$. When GABA or muscimol was delivered concomitantly with high $[\mathrm{K}]_{0}$, no changes in intraterminal [Ca] were detected. This inhibition arises because in the presence of GABA, the GABA-activated $\mathrm{Cl}$ conductance is the dominant determinant of membrane potential in the cell. Even in the face of elevated $[\mathrm{K}]_{o}$, the $\mathrm{Cl}$ conductance prevented the membrane potential from entering the activation range of the voltage-dependent $\mathrm{Ca}$ current, which begins to activate at -50 to $-40 \mathrm{mV}$ and reaches peak inward current at about $-10 \mathrm{mV}$ (Heidelberger and Matthews, 1991, 1992; see Fig. 10). The effect of GABA on membrane potential achieved during high $[\mathrm{K}]_{o}$ is shown in the membrane-voltage recordings of Figure $5 B$, which were obtained from whole-cell patch-clamp measurements in current-clamp mode. Increasing $[\mathrm{K}]_{o}$ to $32 \mathrm{~mm}$ dcpolarized the bipolar neuron from -56 to $-15 \mathrm{mV}$, but when $3 \mu \mathrm{M}$ GABA was applied together with high $[\mathrm{K}]_{o}$, the cell depolarized to only $-46 \mathrm{mV}$, which is insufficient to produce significant activation of $\mathrm{Ca}$ current. In four such experiments, $32 \mathrm{~mm}[\mathrm{~K}]_{o}$ shifted the membrane potential from $-50 \pm 3 \mathrm{mV}$ to $-18 \pm 3 \mathrm{mV}$, but $32 \mathrm{~mm}[\mathrm{~K}]_{o}+3 \mu \mathrm{M}$ GABA caused a depolarization to $-44 \pm 2 \mathrm{mV}$ from the resting level of -48 $\pm 3 \mathrm{mV}$.

As expected from the bicuculline resistance of the GABAactivated $\mathrm{Cl}$ conductance, the inhibition of depolarization-induced $\mathrm{Ca}$ influx by GABA was unaffected by bicuculline methylchloride (Fig. $5 C$ ). In 31 such experiments, GABA reduced the peak increase in $[\mathrm{Ca}]_{i}$ in response to high $[\mathrm{K}]_{0}$ to $19 \pm 5 \%$ of the control level, and GABA + bicuculline was not significantly different, reducing the Ca response to $17 \pm 4 \%$ of control. In contrast, picrotoxin was effective in reversing the inhibition of Ca responses by GABA, as shown in Figurc $5 C$. Thus, the bicuculline-resistant GABA receptors observed in the patchclamp experiments also appear to underlie the inhibition by GABA of increases in $[\mathrm{Ca}]_{i}$ in the synaptic terminal elicited by high $[\mathrm{K}]_{0}$.

A different $\mathrm{GABA}_{\mathrm{A}}$ receptor blocker, SR95531, was also tested on the GABA-activated $\mathrm{Cl}$ conductance in bipolar-cell terminals. Like bicuculline, SR95531 was not an effective blocker, as shown in the current-voltage curves of Figure $6 \mathrm{~A}$. Similarly, 
A

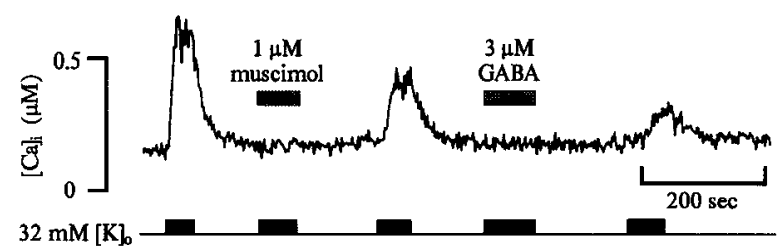

B

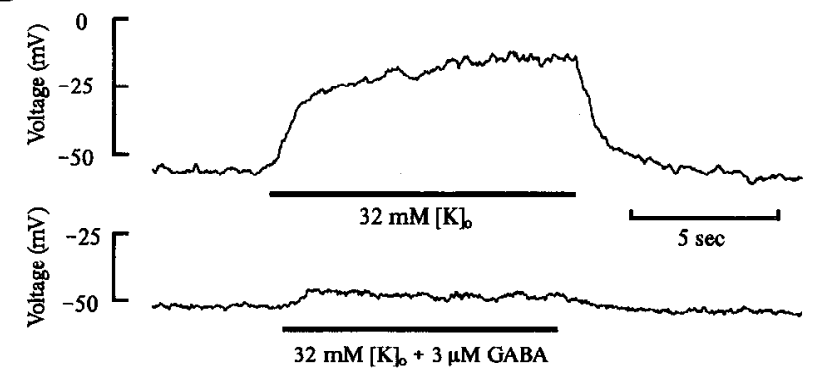

C

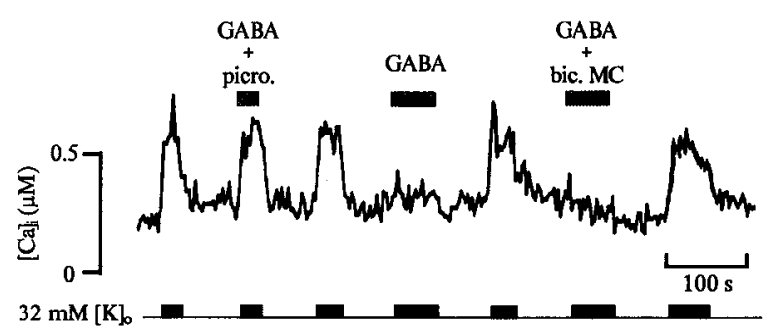

Figure 5. Effects of $\mathrm{GABA}_{\mathrm{A}}$ agonists and antagonists on increase in $[\mathrm{Ca}]_{i}$ elicited by high $[\mathrm{K}]_{,}$. [Ca], was measured in single synaptic terminals of isolated bipolar neurons by filling cells with fura-2AM. $A$, Elevating [K], from 2.6 to $32 \mathrm{~mm}$ increased [Ca] in a bipolar-cell synaptic terminal, but not when $1 \mu \mathrm{M}$ muscimol or $3 \mu \mathrm{M}$ GABA was applied simultaneously with the high $[\mathrm{K}]$. Applications were made by exchanging the bath solution. $B$, Records of membrane voltage during local application of $32 \mathrm{~mm}[\mathrm{~K}]_{,}$(top trace) or $32 \mathrm{~mm}[\mathrm{~K}]_{\sigma}$ with $3 \mu \mathrm{M} \mathrm{GABA}$. In this recording, potassium channels were not blocked, and the pipette solution contained $\mathrm{K}$-gluconate and no TEA. $C$, The increase in $[\mathrm{Ca}]_{i}$ in a synaptic terminal in response to $32 \mathrm{~mm}[\mathrm{~K}]$, was abolished by 3 $\mu \mathrm{M}$ GABA (middle gray bar), but not when $30 \mu \mathrm{M}$ picrotoxin was included with the GABA and high $\mathrm{K}$ (first gray bar). The effect of GABA on the $\mathrm{K}$-induced increase in $\mathrm{Ca}$ was not affected by $50 \mu \mathrm{M}$ bicuculline methylchloride (third gray bar). Thus, picrotoxin blocked the effect of GABA, but bicuculline did not.

SR95531 was not able to reverse the inhibition by GABA of $\mathrm{Ca}$ influx elicited by high $[\mathrm{K}]_{o}$ (Fig. $6 B$ ). This is another indication that the pharmacology of GABA receptors found in synaptic terminals of retinal bipolar neurons differs from that of GABA receptors in other neurons.

Because of the unusual pharmacology of the GABA-activated conductance, we considered the possibility that the receptor might be sensitive to a different neurotransmitter in addition to GABA. To examine this, we tested a number of transmitters found in the retina. The most obvious possibility is glycine, which is found in some amacrine cells in goldfish retina (Marc and Lam, 1981) and is commonly found to activate $\mathrm{Cl}$ channels in neurons. At 10-50 $\mu \mathrm{M}$, glycine had no effect on the resting conductance of bipolar neurons $(n=10)$ and had no effect on the activation of $\mathrm{Cl}$ conductance by GABA. Other transmitters that were found to have no effect on membrane ionic conductance were $\mathrm{ACh}$, norepinephrine, and dopamine. A variety of
A
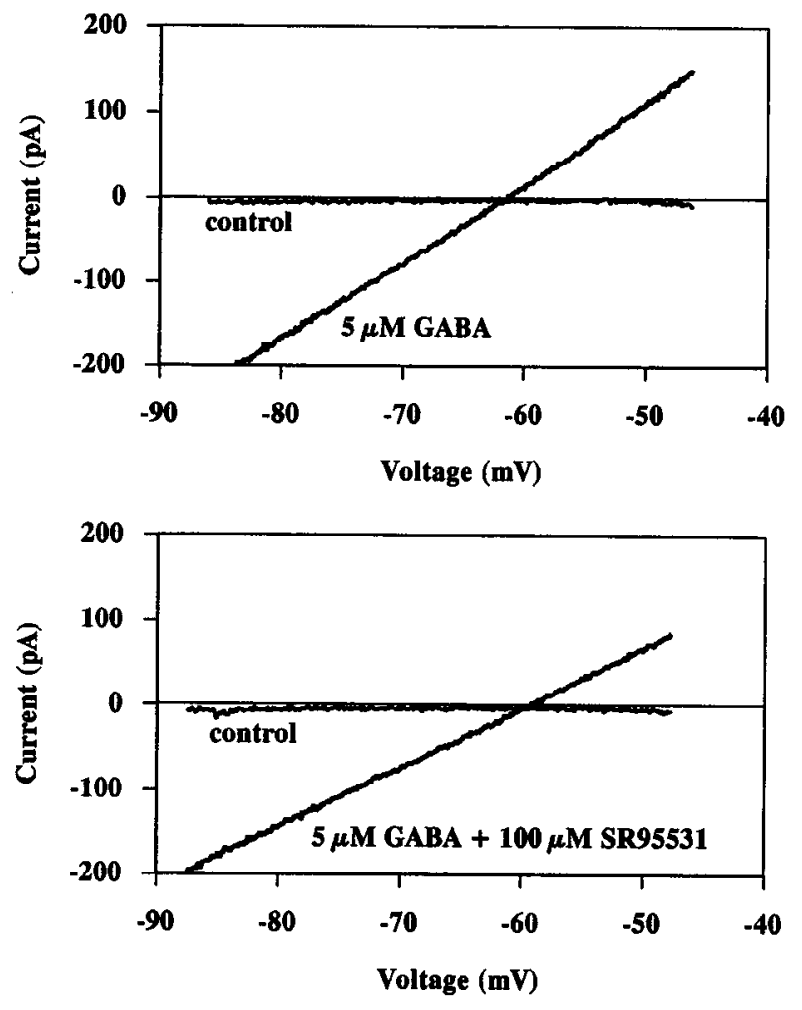

B

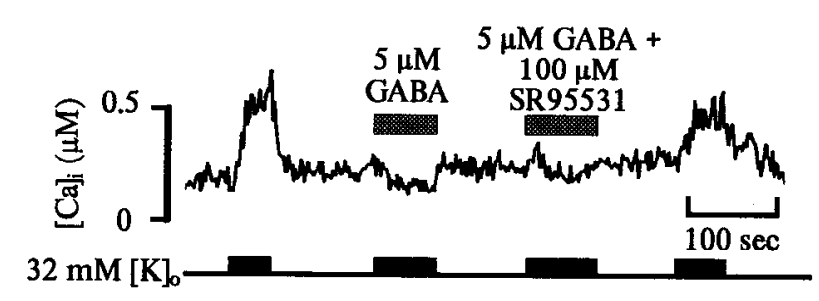

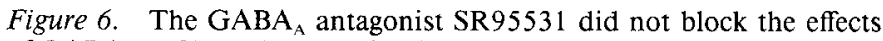
of $\mathrm{GABA}$ on $\mathrm{Cl}$ conductance in bipolar-cell synaptic terminals. $A, \mathrm{Cur}$ rent-voltage relations showing activation of $\mathrm{Cl}$ conductance by $5 \mu \mathrm{M}$ GABA in the presence and absence of $100 \mu \mathrm{M}$ SR 95531. Pipette solution contained $\mathrm{Cs}^{-}$gluconate/TEA-Cl, and GABA-current reversed near -60 $\mathrm{mV} . B$, SR95531 was also unable to reverse the effect of GABA on the increase in $[\mathrm{Ca}]_{i}$ in a synaptic terminal elicited by high $[\mathrm{K}]_{0}$.

neuropeptides are also found in amacrine cells in goldfish retina (Marshak, 1992), but none of those we examined (substance $P$, met- and leu-enkephalin, somatostatin, and vasoactive intestinal peptide) affected membrane conductance.

\section{$G A B A_{B}$ receptors are not linked to conductance changes in synaptic terminals}

Resistance to blockade by bicuculline is one pharmacological criterion used to define the other major class of $\mathrm{GABA}$ receptor, the $\mathrm{GABA}_{\mathrm{B}}$ receptor. To establish whether these receptors might be involved in the activation of $\mathrm{Cl}$ conductance by GABA in bipolar-cell synaptic terminals, we examined the effects of baclofen, a GABA G $_{\mathrm{B}}$ agonist (Bowery et al., 1980), and

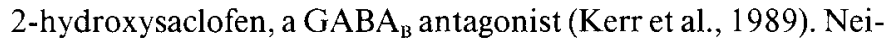
ther drug had a detectable effect. At concentrations of $50 \mu \mathrm{M}$ to $1 \mathrm{~mm}$, baclofen produced no change in membrane conductance in bipolar cells. Because baclofen might affect potassium chan- 


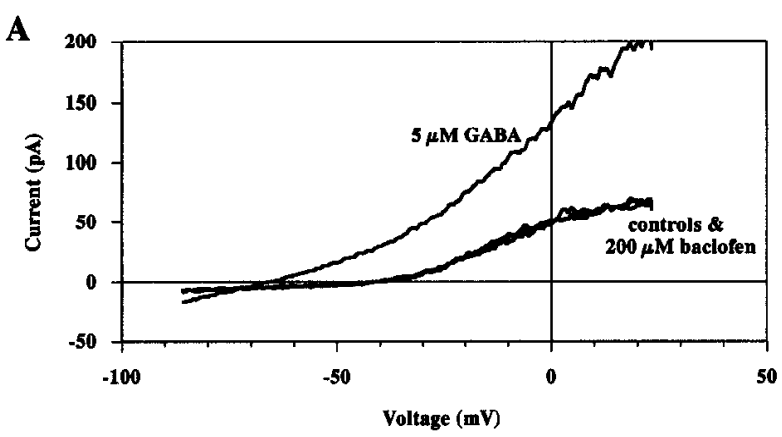

B

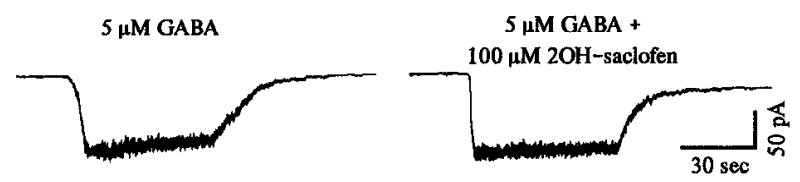

C

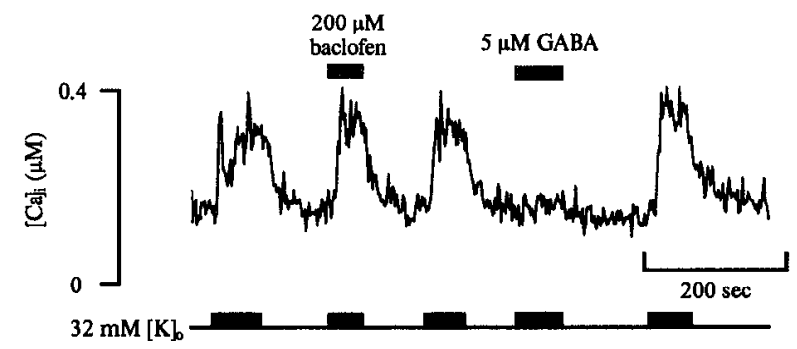

Figure 7. $\mathrm{GABA}_{\mathrm{B}}$ agonists and antagonists had no effect on bipolarcell synaptic terminals. $A$, The $\mathrm{GABA}_{\mathrm{B}}$ agonist baclofen had no effect on the membrane conductance of the bipolar cell, but $\mathrm{Cl}$ conductance was activated by GABA. Traces show unsubtracted membrane currents in response to linear voltage ramps at $100 \mathrm{mV} / \mathrm{sec}$. The two superimposed control traces, which are indistinguishable from the trace during application of baclofen, were obtained before application of drugs and after their removal. In this cell, potassium conductance was unblocked so that any effect of baclofen on $\mathrm{K}$ channels might have been rcvealcd; the pipette solution contained $\mathrm{K}$-gluconate without TEA. The reversal potential for the GABA current is more negative than typical because omission of TEA reduces internal $[\mathrm{Cl}]$ by an additional $10 \mathrm{mM}$. $B$, The conductance change induced by $5 \mu \mathrm{M}$ GABA was unaffected by the $\mathrm{GABA}_{\mathrm{B}}$ antagonist 2-hydroxysaclofen (2OH-saclofen). Traces show membrane currents at a holding potential of $-60 \mathrm{mV}$ in a cell recorded with a high-Cl pipette solution. $C$, Baclofen had no effect on the increase in $[\mathrm{Ca}]_{i}$ in a synaptic terminal elicited by high $[\mathrm{K}]_{o}$, but $\mathrm{GABA}$ had its usual effect.

nels (Gähwiler and Brown, 1985) rather than chloride channels, experiments with baclofen were also done without blocking potassium channels [K-gluconate rather than Cs-gluconate pipette solution; no TEA). An example is shown in Figure $7 A$; GABA had its usual effect on $\mathrm{Cl}$ conductance, but the current-voltage curves in the presence of baclofen were not detectably different from the resting state. The response to GABA was also unaffected by 2-hydroxysaclofen, as shown in Figure $7 \mathrm{~B}$. In eight cells, the conductance change elicited by $5 \mu \mathrm{M} \mathrm{GABA}+100$ $\mu \mathrm{M}$ 2-hydroxysaclofen was $109 \pm 8 \%$ of the response to GABA alone. Although the $\mathrm{GABA}$-activated $\mathrm{Cl}$ conductance is resistant to block by bicuculline and SR 95531, its pharmacology is clearly not consistent with a role for $\mathrm{GABA}_{\mathrm{B}}$ receptors. Additionally, there was no effect of baclofen on the increase in $[\mathrm{Ca}]_{i}$ in synaptic terminals in response to elevated $[\mathrm{K}]_{o}$, as shown in Figure $7 \mathrm{C}$.

\section{Effects of "GABAC, agonists on Cl conductance}

Because the GABA receptors activating the $\mathrm{Cl}$ conductance are insensitive to both bicuculline and baclofen, we examined activation of $\mathrm{Cl}$ conductance by 4 -aminocrotonic acid (ACA), which has been reported to bind to such " $\mathrm{GABA}_{c}$ " receptors (Johnston et al., 1975; Drew et al., 1984). ACA is simply GABA with a double bond instead of a single bond between carbons 2 and 3; because of the double bond, the molecule is conformationally inflexible and is locked in either the folded form (CACA) or the extended form (TACA). Both TACA and CACA were found to activate the $\mathrm{Cl}$ conductance of single terminals, but TACA was more potent than CACA. As shown in Figure $8 \mathrm{~A}$, $20 \mu \mathrm{M}$ CACA produced approximately the same conductance change in a bipolar cell as $1 \mu \mathrm{M}$ GABA. However, TACA and GABA had comparable effects at $1 \mu \mathrm{M}$ (Fig. $8 B$ ). The average conductance increase is plotted as a function of drug concentration for both TACA and CACA in Figure $8 C$; the $K_{1 / 2}$ for TACA was about $3 \mu \mathrm{M}$, which is comparable to that for GABA (see Fig. 3), while the $K_{1 / 2}$ for CACA was approximately $50 \mu \mathrm{M}$. This is the potency pattern expected for $\mathrm{GABA}_{\mathrm{A}}$ receptors (Johnston et al., 1975). Although the activation of the conductance by CACA might be taken as evidence that the GABA receptor linked to activation of $\mathrm{Cl}$ current in the synaptic terminal is a GABA . receptor (e.g., Feigenspan et al., 1993), it is more appropriate to view these results in terms of the conformational specificity of the receptor for GABA (see Ayoub and Matthews, 1991). Given the close structural similarity of TACA and CACA to GABA, these conformationally locked GABA analogs might give information about the stereoisomer of $\mathrm{GABA}$ preferred by the receptor, as suggested in the initial report of synthesis of the analogs (Johnston et al., 1975).

\section{Effects of GABA on calcium current in the synaptic terminal}

Heidelberger and Matthews (1991) showed that, in addition to the effect of GABA on $\mathrm{Cl}$ conductance, as detailed above, GABA also inhibited $\mathrm{Ca}$ current in the bipolar-cell synaptic terminal. This inhibition was not produced by muscimol or blocked by picrotoxin, both of which affect the GABA-activated $\mathrm{Cl}$ conductance (see above), nor was it reproduced by baclofen or blocked by 2-hydroxysaclofen. That is, the pharmacology of this effect matched neither $\mathrm{GABA}_{\mathrm{A}}$ nor $\mathrm{GABA}_{\mathrm{B}}$ receptors. For that reason, we examined the effect of $C A C A$, the putative $G A B A_{C}$ agonist, on the Ca current in the synaptic terminal.

Figure $9 A$ shows that $\mathrm{Ca}$ current elicited by a depolarizing step is reduced by GABA but not by baclofen in the same cell; on average, $5 \mu \mathrm{M} \mathrm{GABA}(+100 \mu \mathrm{M}$ picrotoxin to block $\mathrm{Cl}$ conductance) reduced Ca current by $30 \pm 3 \%$ (mean $\pm \mathrm{SEM} ; n=$ 21), while baclofen at $50 \mu \mathrm{M}$ to $1 \mathrm{mM}$ had no significant effect, reducing the current by $6 \pm 3 \%$ in 12 cells (efficacy of the baclofen was confirmed in rat spinal cord; K. Peshori, personal communication). CACA, on the other hand, proved to be a potent and selective inhibitor of $\mathrm{Ca}$ current, as illustrated in Figure $9 B$. Unlike the effect of $\mathrm{CACA}$ on $\mathrm{Cl}$ conductance, where CACA was considerably less potent than either GABA or TACA, the concentration at which CACA was effective in inhibiting $\mathrm{Ca}$ current was at least comparable to GABA: at $1 \mu \mathrm{M}$ CACA, the average suppression of $\mathrm{Ca}$ current was $23 \pm 4 \%(n=18)$, and at $5 \mu \mathrm{M}$, the average suppression was $33 \pm 5 \%(n=13)$. Thus, at concentrations below about $10 \mu \mathrm{M}, \mathrm{CACA}$ is a relatively selective agonist for the receptor mediating the inhibition of $\mathrm{Ca}$ 

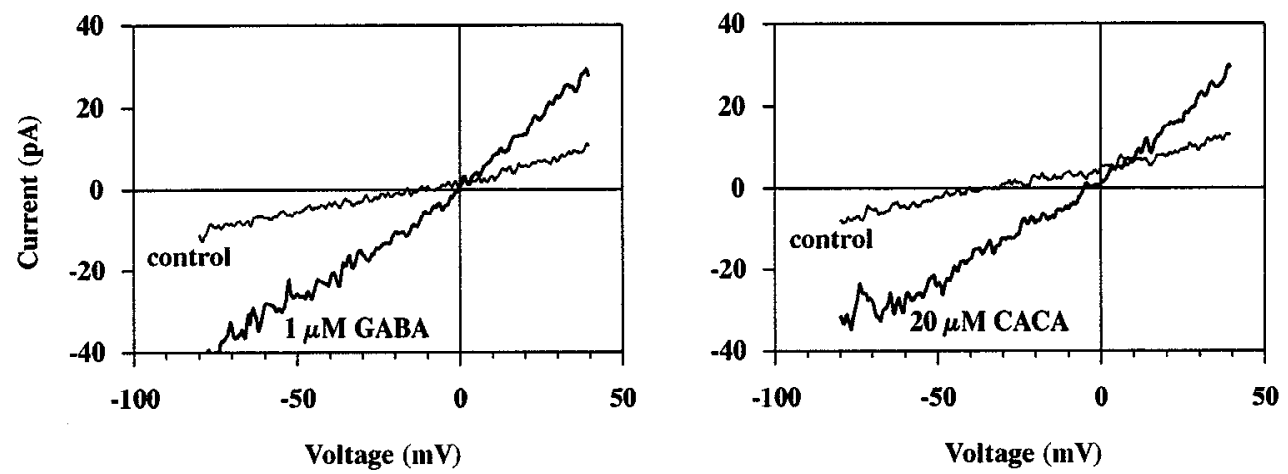

B
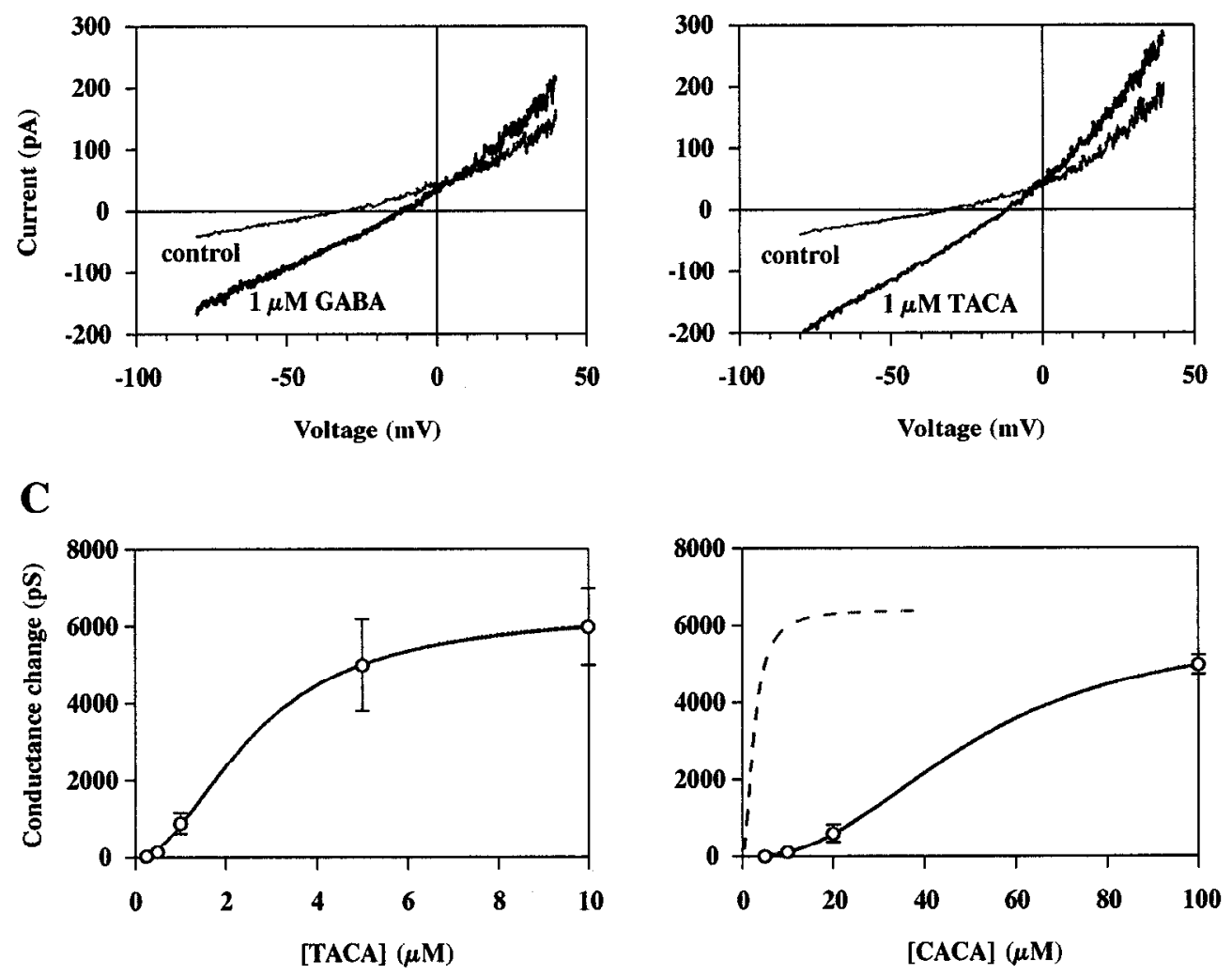

Figure 8. Comparison of actions of GABA and the conformationally locked GABA analogs TACA and CACA on $\mathrm{Cl}$ conductance. $A$, Current-voltage relations in the presence and absence of $1 \mu \mathrm{M}$ GABA and $20 \mu \mathrm{M}$ CACA in the same bipolar neuron. Traces show unsubtracted membrane currents in response to voltage ramps at $100 \mathrm{mV} / \mathrm{sec}$. The pipette solution contained high $[\mathrm{Cl}]$. $B$, Current-voltage relations from voltage ramps in the presence and absence of $1 \mu \mathrm{M}$ GABA and $1 \mu \mathrm{M}$ TACA. Different cell from $A$. The pipette solution contained high $[\mathrm{Cl}] . C$, Dose-response relations for activation of $\mathrm{Cl}$ conductance by TACA (left panel) and CACA. The solid lines were drawn according to the relation $g=g_{\max } /\left(1+\left(K_{1 / 2} /[\mathrm{ACA}]\right)^{n}\right)$, where $g_{\max }=6400 \mathrm{pS}, K_{1 / 2}=2.6 \mu \mathrm{M}$, and $n=2.0$ for TACA, and $g_{\max }=5950$ $\mathrm{pS}, K_{\mathrm{t} / 2}=50 \mu \mathrm{M}$, and $n=2.4$ for CACA Note the 10-fold difference in concentration scales in the two panels. The dashed line in the right panel shows the fitted curve for TACA (left panel) replotted on the concentration scalc appropriate for CACA.

current, without significant activation of the $\mathrm{Cl}$ conductance (see Fig. $8 C$ ).

The inhibition of Ca current by CACA was voltage dependent, and could be overcome by sufficient depolarization, as reported previously for GABA-induced inhibition of $\mathrm{Ca}$ current by $\mathrm{Hei}$ delberger and Matthews (1991). As illustrated in the currentvoltage relations in Figure 10A, the greatest amount of inhibition of Ca current by CACA occurred in the physiological range of activation of the bipolar cell by light, that is, from approximately -50 to $-20 \mathrm{mV}$. The difference curve showing the amount of current suppressed by CACA as a function of voltage is shown in Figure $10 B$; for this cell, the peak suppression of current was reached at $-25 \mathrm{mV}$. On average, the membrane potential at which pcak suppression occurred was $-25 \pm 1 \mathrm{mV}(n=26)$. Expressed as a proportion of the control Ca current in the absence of CACA, the suppression by CACA was strongest at somewhat more negative potentials (Fig. 10C). That is, although the absolute amount of current suppressed at $-40 \mathrm{mV}$ was smaller than at $-25 \mathrm{mV}$, the suppressed current accounted for a larger proportion of the normal current at $-40 \mathrm{mV}$ than at $-25 \mathrm{mV}$. Because the large-terminal bipolar cells recorded here are ON-type (depolarizing) cells (Saito et al., 1983), the inhibition of $\mathrm{Ca}$ current might have important functional consequences for the response to dim and moderate illumination. If the dark potential is assumed to be -60 to $-50 \mathrm{mV}$, then activation of the mechanism illustrated in Figure $10 \mathrm{C}$ should have profound effects on the amount of $\mathrm{Ca}$ influx into the terminal, and hence the amount of transmitter released, in response to small to moderate depolarizations.

\section{GTP dependence of inhibition of $C$ a current by CACA}

With the standard pipette solution containing $0.3 \mathrm{~mm}$ GTP, inhibition of Ca current by CACA could typically be observed repeatedly for the duration of the whole-cell recording (up to 1 $\mathrm{hr}$ ). When GTP was removed and $0.5-1.0 \mathrm{~mm}$ GDP- $\beta-\mathrm{S}$ was added to the pipette solution, the response to CACA progressively decreased, and commonly disappeared within 5-10 min. Examples of the current suppressed by CACA are shown in 
A
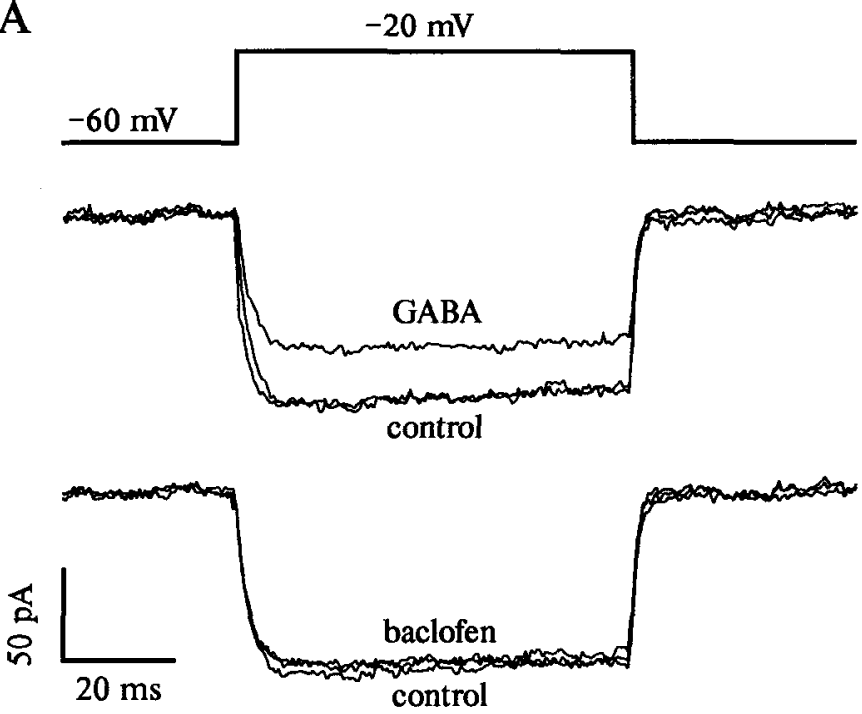

B

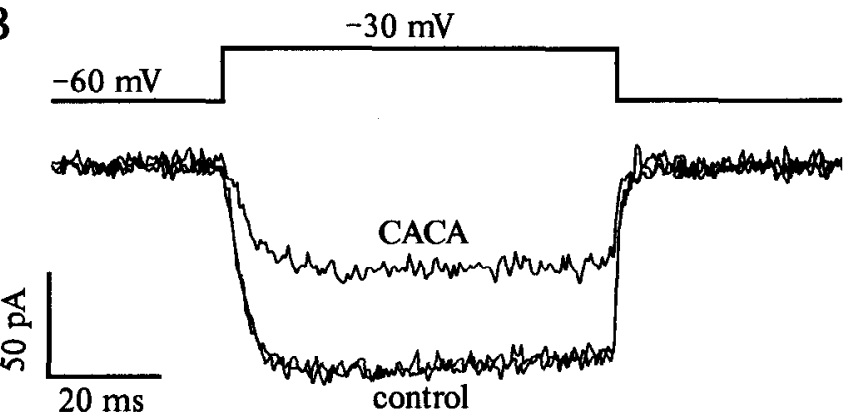

Figure 9. Inhibition of calcium current by GABA and CACA. A, Traces show inward $\mathrm{Ca}$ current elicited by a voltage step from $-60 \mathrm{mV}$ to $-20 \mathrm{mV}$ for $70 \mathrm{msec}$. Control traces show current before application and after removal of drug. GABA $(1 \mu \mathrm{M}+100 \mu \mathrm{M}$ picrotoxin $)$ reversibly reduced the Ca current, but in the same cell, baclofen $(200 \mu \mathrm{M})$ did not affect the current. $B$, The $\mathrm{GABA}_{C}$ agonist CACA $(5 \mu \mathrm{M})$ also inhibited $C a$ current. For traces in $A$ and $B$, leak and capacitative currents were subtracted using a $P / 6$ protocol.

Figure $11, A$ and $B$, at early and later times after onset of recording for cells recorded with GTP and with GDP- $\beta$-S; average values of the percentage suppression for eight cells with each pipettc solution are shown in Figure 11C. The amplitude of the control $\mathrm{Ca}$ current itself did not decline appreciably during the recording with either pipette solution. The binding of GTP to G-proteins is competitively inhibited by GDP- $\beta$-S (Eckstein et al., 1979), and thus the effect of GDP- $\beta$-S suggests that GTP is required for the linkage between CACA receptor and inhibition of the $\mathrm{Ca}$ current, as expected, for example, if a G-protein is involved in the linkage (Dolphin, 1990).

In other instances in which G-proteins are thought to mediate the action of a neurotransmitter on ionic conductance, the nonhydrolyzable GTP analog GTP- $\gamma-\mathrm{S}$ has been found to alter the dynamics of the neurotransmitter effect, presumably by causing persistent activation of G-proteins (Rodbell, 1980). For example, GTP- $\gamma-\mathrm{S}$ has been reported to enhance the inhibition of Ca current by GABA in DRG cells and retard the recovery of the current (Dolphin and Scott, 1987); in sympathetic ganglion neurons, neurotransmitter inhibition of $\mathrm{Ca}$ current is rendered irreversible by GTP- $\gamma$-S (Bley and Tsien, 1990). In bipolar-cell
$\mathbf{A}$
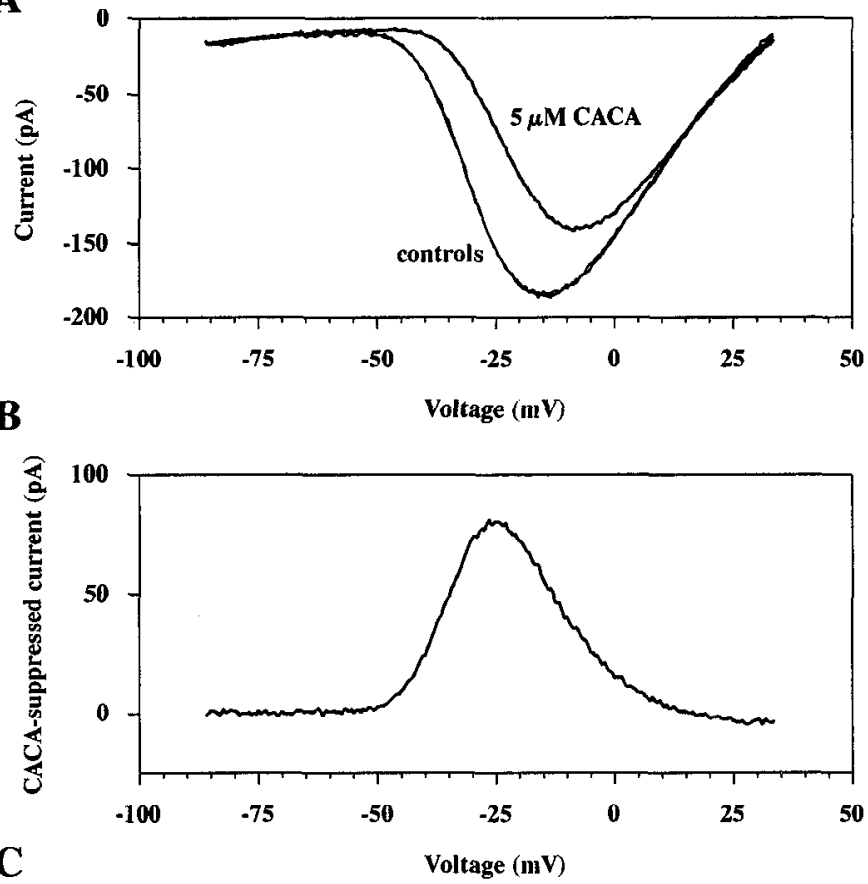

C

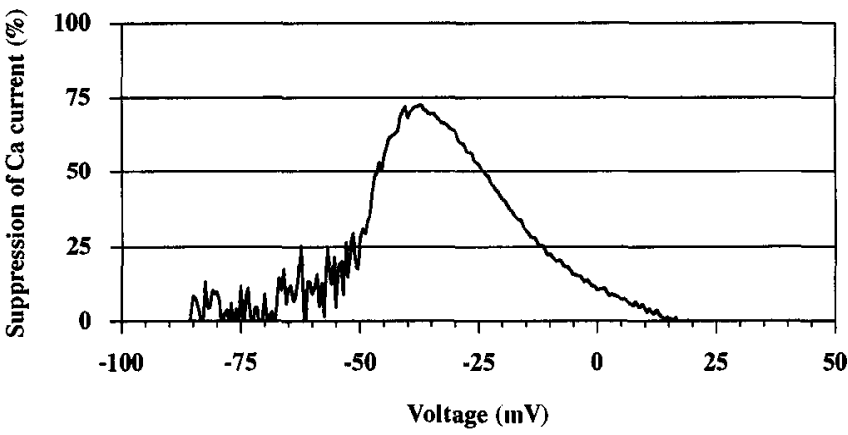

Figure 10. Voltage dependence of inhibition of $\mathrm{Ca}$ current by CACA. $A$. Current-voltage relations measured with linear voltage ramps at 100 $\mathrm{mV} / \mathrm{sec}$ in presence and absence of $5 \mu \mathrm{M}$ CACA. Traces are averages of five separate applications of CACA presented during a $30 \mathrm{~min}$ recording from an isolated synaptic terminal. The superimposed control traces were taken before each application and after recovery of current following removal of CACA. Traces are raw membrane current without subtraction of leak or capacitative current. $B$, Difference current showing that CACA-dependent current, obtained by subtracting control currentvoltage relation from the relation in the presence of CACA for the traces shown in $A$. The amount of current suppressed by CACA reached a peak at about $-25 \mathrm{mV}$ and declined with increasing depolarization. $C$, The difference current in $B$ expressed as a percentage of the control current observed at each voltage in the absence of CACA. This shows that CACA removed a large fraction of the Ca current in the voltage range near the resting state of the bipolar neuron in darkness $(-50$ to $-40 \mathrm{mV})$.

synaptic terminals, however, the effect of CACA on Ca current was not dramatically altered by replacing GTP in the pipette solution with $0.5-1 \mathrm{~mm}$ GTP- $\gamma-\mathrm{S}$. The suppression was somewhat enhanced by GTP- $\gamma-\mathrm{S}$, but the difference reached only marginal statistical significance (see Fig. 12A). The reversibility and persistence of CACA's action appeared to be normal with GTP- $\gamma-\mathrm{S}$. An example of this behavior from a long-lasting recording from an isolated synaptic terminal is shown in Figure $12 B$. It is possible that dialysis of endogenous GTP was insufficiently complete to prevent its competition with $\mathrm{GTP}_{-\gamma-\mathrm{S}}$, but this is difficult to reconcile with the relatively rapid elimination 
A

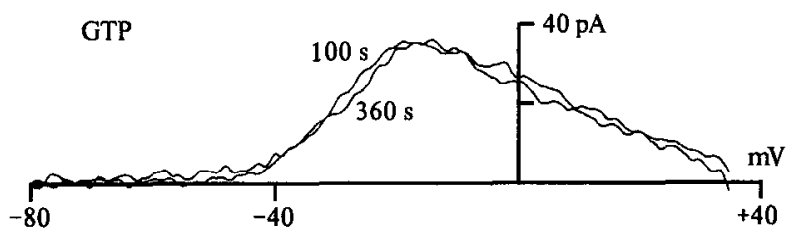

B

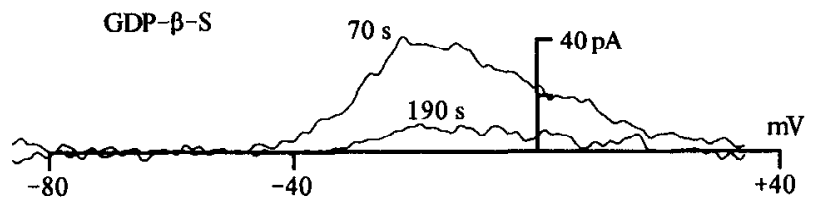

$\mathrm{C}$

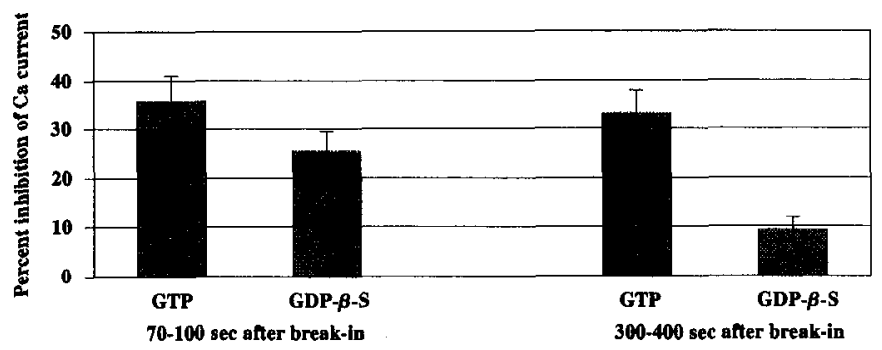

Figure 11. Inhibition of Ca current by CACA depends on GTP. $A$, Difference currents showing current suppressed by $1 \mu \mathrm{M}$ CACA at the indicated times after onset of the whole-cell recording. Difference currents were obtained as for Figure 10. The upper traces were obtained with a pipette solution containing $0.3 \mathrm{~mm}$ GTP, while the lower traces were recorded from a different cell with a pipette solution containing $0.5 \mathrm{~mm}$ GDP- $\beta$-S and no GTP. With GTP-containing pipette solution, reversible inhibition of $\mathrm{Ca}$ current by CACA could ordinarily be recorded for up to $1 \mathrm{hr}$ during whole-cell recording, but when GDP- $\beta-S$ replaced GTP, inhibition by CACA typically disappeared within $300-$ $500 \mathrm{sec}$. The average behavior of eight cells with GTP and eight cells with GDP- $\beta-S$ is shown in $C$. Error bars indicate \pm 1 SEM.

of the CACA response by GDP- $\beta-S$ in similar experiments. Alternatively, the lack of a dramatic effect of GTP- $\gamma-S$ may indicate that the GTP-requiring process does not depend on hydrolysis of GTP for reversal upon removal of CACA.

Because the effect of CACA on the current-voltage relation of the $\mathrm{Ca}$ current is reminiscent of the effect of external acidification on Ca current in photoreceptors (Barnes and Bui, 1991), we examined whether the CACA response might be related to changes in external or internal $\mathrm{pH}$, rather than a receptor-mediated event. Several lines of evidence suggest that $\mathrm{pH}$ changes are not involved. First, addition of $1 \mathrm{~mm}$ CACA or GABA to the external solution (a concentration approximately 1000-fold higher than the effective dose for inhibition of Ca current) caused no detectable change in $\mathrm{pH}$. Second, varying the HEPES concentration in the external solution from 5-25 mM had no effect on inhibition of Ca current by CACA. Finally, altering the buffer capacity of the pipette solution with which cells were dialyzed (3, 5,10 , or $25 \mathrm{~mm}$ HEPES; 3 or $5 \mathrm{~mm}$ Tris) had no detectable effect on the inhibition.

\section{Variability of response of Ca current to CACA}

All of the experiments reported here were performed on freshly isolated bipolar cells obtained each day from a new retinal preparation. For cells within a preparation, the effectiveness of CACA in inhibiting $\mathrm{Ca}$ current was consistent across cells. However,
A

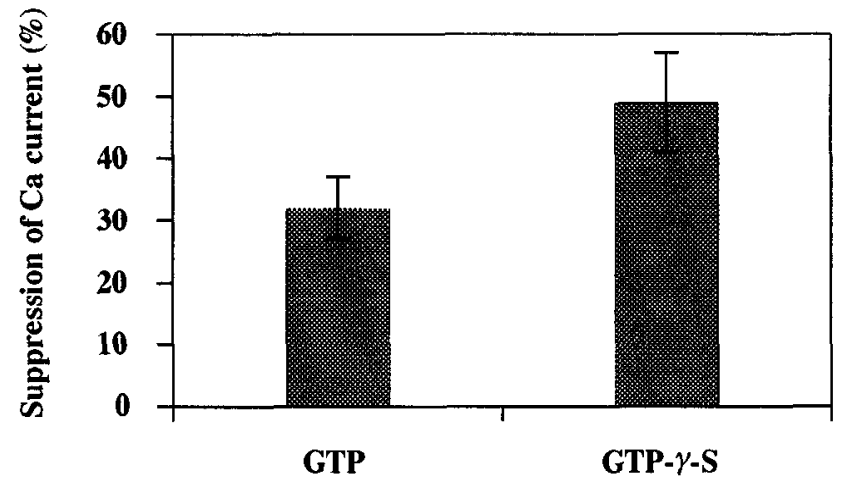

B

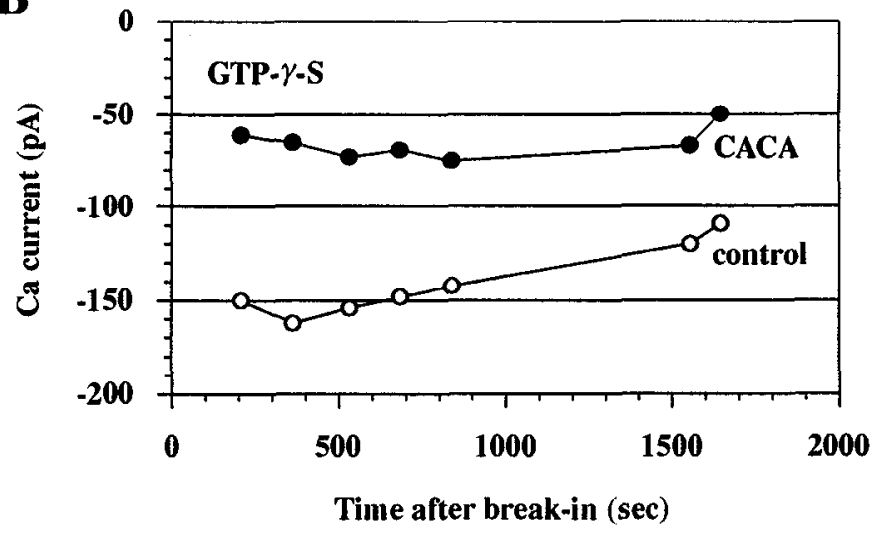

Figure 12. Inhibition of Ca current by CACA in the presence of GTP$\gamma-\mathrm{S} . A$, The average percentage suppression of Ca current by $1 \mu \mathrm{M} \mathrm{CACA}$ was measured 300-500 sec after onset of whole-cell recording for eight cells with GTP-containing pipette solution and five cells with $0.5 \mathrm{~mm}$ GTP- $\gamma-S$ instead of GTP. Error bars show \pm 1 SEM. The increase in suppression in the presence of GTP- $\gamma-\mathrm{S}$ was marginally significant at $p$ $<0.05$ ( $t$ statistic). $B$, Suppression of Ca current by CACA was stable and reversible during prolonged whole-terminal recording in the presence of GTP- $\gamma-\mathrm{S}$. The control currents (open circles) represent the average of the currents before application and after removal of CACA at each indicated time point. The solid circles show the current during application of CACA. Current amplitude was measured at $-25 \mathrm{mV}$, which is approximately the voltage of peak suppression of current by CACA (Fig. 10). The pipette solution contained $0.5 \mathrm{~mm} \mathrm{GTP- \gamma -S}$ and no GTP. Recording was from an isolated synaptic terminal.

there was considerable variability across preparations, and in some preparations there was no detectable effect of CACA (or GABA) on Ca current, even though the Ca current itself was large and stable. Taking a peak suppression of $10 \%$ or more as a cutoff for responsiveness, we found that $60 \%$ of the preparations in which CACA was tested showed inhibition of $\mathrm{Ca}$ current. The reason for this variability is unclear and may be due to factors such as presence of the CACA receptor only on a subpcpulation of large-terminal bipolar cells that dominate in certain preparations but not others, presence of the receptor on a part of the terminal surface that is obtained in some enzymatic digestions but not others, or variation in proteolysis of the receptor by papain.

In the preparations that responded to CACA, CACA inhibited the Ca current in all of the bipolar neurons that had morphology like that shown in Figure 1 (i.e., type Mbl bipolar cells). Two cells were encountered, however, that had unusual morphology and unusual responses to CACA. Although the synaptic ter- 
minals were as large as those of $\mathrm{Mbl}$ cells, the axon was unusually short (approximately $10 \mu \mathrm{m}$ ), so that the overall cell length was likely insufficient for the terminal to have reached the proximal inner plexiform layer (sublamina b) where terminals of true Mbl bipolar cells are found (Sherry and Yazulla, 1993). For this reason, the two unusual cells may have been large-terminal OFF bipolar cells (hyperpolarized by light) of the kind recently described in goldfish retina and called type Ma-L by Sherry and Yazulla (1993). Interestingly, in these two cells the effect of CACA on Ca current was the reverse of that typically seen in type $\mathrm{Mbl}$ bipolar cells; that is, CACA enhanced $\mathrm{Ca}$ current, rather than inhibiting it, and shifted the activation range toward more negative potentials, rather than more positive potentials. This was never observed in any other cells. If these cells were actually OFF cells, then a negative shift in Ca current activation range would be the appropriate direction to oppose the light response, just as a positive shift is appropriate to oppose the depolarizing light response of ON cells. The mechanism might work as follows in intact retina. The membrane potential of ON cells is more negative in the dark, and illumination depolarizes the cell and activates $\mathrm{Ca}$ current; feedback release of GABA would then shift the activation range of the Ca current in the positive direction, so less Ca current would be activated at the more depolarized voltage achieved in the light. OFF cells, on the other hand, are depolarized in the dark, and illumination hyperpolarizes the cell and deactivates Ca current; GABA released upon illumination would then shift the activation range of the Ca current more negative, so more current would be activated at the negative membrane potential attained in the light. In both types of cell, the shift in activation range of $\mathrm{Ca}$ current would tend to oppose the effect of illumination on transmitter release by restoring the dark state of the $\mathrm{Ca}$ current, that is, active in OFF cells and inactive in ON cells.

\section{Discussion}

\section{Pharmacology of the GABA-activated $\mathrm{Cl}$ conductance}

Our experiments demonstrate that GABA activates a $\mathrm{Cl}$ conductance in the synaptic tcrminal of bipolar neurons, but that this conductance is insensitive to the $\mathrm{GABA}_{\mathrm{A}}$ antagonists bicuculline and SR95531. Further, this bicuculline-resistant $\mathrm{Cl}$ conductance underlies the inhibition by GABA of depolarization-induced calcium influx in the synaptic terminal, measured in fura- 2 experiments. Lack of blockade by bicuculline has been used to argue for a novel class of $\mathrm{GABA}$-activated $\mathrm{Cl}$ channel,

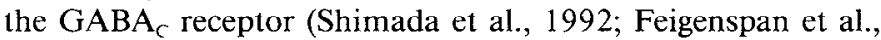
1993; Qian and Dowling, 1993). However, in view of the heterogeneity of $\mathrm{GABA}_{A}$-receptor subunits revealed by molecular biological studies (Burt and Kamatchi, 1991), other criteria in addition to bicuculline resistance would seem to be required. Although sensitivity to bicuculline has long been considered a defining property of $\mathrm{GABA}_{\mathrm{A}}$ receptors, molecular cloning and functional expression experiments demonstrate that this is not a necessary feature of $\mathrm{GABA}$-activated $\mathrm{Cl}$ channels. GABA receptors expressed from various combinations of subunits show widely varying pharmacology (Levitan et al., 1988; Sigel et al., 1990), and substitution of a single amino acid can dramatically reduce the affinity of GABA receptors for bicuculline and SR95531 (Sigel et al., 1992). Given that bicuculline resistance can arise from simple alterations of $\mathrm{GABA}_{\mathrm{A}}$-family receptors, there is no compelling reason to base receptor classification on this pharmacological criterion. In addition, polyA+ RNA from retina expresses bicuculline-insensitive GABA receptors in oo- cytes (Woodward et al., 1992), and a retina-specific subunit has been identified ( $\rho_{1}$; Cutting et al., 1991) that yields bicucullineresistant GABA-activated $\mathrm{Cl}$ channels (Shimada et al., 1992). Thus, naturally occurring bicuculline-resistant GABA receptors that activate $\mathrm{Cl}$ channels are found in retina, and it seems likely that the $\mathrm{Cl}$ conductance described here in bipolar-cell terminals is due to GABA-activated $\mathrm{Cl}$ channels containing the $\rho_{1}$ subunit or a similar subunit (see below).

\section{Pharmacology of the effect of $G A B A$ on calcium current}

We have shown that inhibition of $\mathrm{Ca}$ current via GABA receptors requires $\mathrm{GTP}$, but that $\mathrm{GABA}_{\mathrm{B}}$ agonists and antagonists have no effect (Heidelberger and Matthews, 1991; present results). Further, the proposed $\mathrm{GABA}_{\mathrm{C}}$ agonist CACA inhibited Ca current at $1 \mu \mathrm{M}$ or below, whereas its $K_{1 / 2}$ for activation of $\mathrm{Cl}$ conductance was $50 \mu \mathrm{M}$. In light of this, the term " $\mathrm{GABA}{ }_{C}$ receptor" might seem more justifiable for baclofen-insensitive $\mathrm{GABA}_{\mathrm{B}}$ receptors than for bicuculline-insensitive $\mathrm{GABA}_{\mathrm{A}}$ receptors. Although we have referred to baclofen-insensitive GA$\mathrm{BA}_{\mathrm{B}}$-like receptors in exactly this way in the title of an abstract (Matthews et al., 1991), the basis for placing these receptors in a new class is inadequate. By extension of the arguments made above for $\mathrm{GABA}_{\mathrm{A}}$ receptors, variation in affinities for agonist and antagonist binding by a $\mathrm{CABA}_{\mathrm{B}}$ receptor might also be accomplished with simple changes in subunit composition and/ or amino acid sequence. Molecular information about the GA$\mathrm{BA}_{\mathrm{B}}$ receptor is not yet available, but it seems likely that a baclofen-insensitive form could result without changes in the protein large enough to justify creation of a new receptor class.

\section{$G A B A_{C}$ receptors}

The term $\mathrm{GABA}_{C}$ receptor has been proposed for GABA receptors that are insensitive to both bicuculline and baclofen. In the large synaptic terminal of goldfish retinal bipolar neurons, however, there are two distinct types of such bicuculline/baclofen-resistant receptors: one coupled to $\mathrm{Cl}$ channels and one coupled via a GTP-requiring process to $\mathrm{Ca}$ channels. It seems inappropriatc to call both of them $\mathrm{GABA}_{C}$ receptors, based on their shared insensitivity to bicuculline and baclofen, when one is a $\mathrm{GABA}_{\wedge}$-type receptor and the other a $\mathrm{GABA}_{\mathrm{B}}$-type receptor. Instead, it is preferable to allow for the diversity in pharmacology that accompanies the diversity of subunits within the $\mathrm{GABA}_{\mathrm{A}}$ family and, apparently, within the putative $\mathrm{GABA}_{\mathrm{B}}$ family of receptors. In the goldfish bipolar-cell terminal, the conformationally locked GABA analog CACA has proved useful in selectively activating the Ca current mechanism without activating the $\mathrm{Cl}$ conductance, and perhaps it will be useful in identifying other baclofen-resistant $\mathrm{GABA}_{\mathrm{B}}$ receptors in the nervous system.

It should also be pointed out that the retina contains many different kinds of bipolar cell, and we have focused on a single type, selected because of its large synaptic terminal. Other types of bipclar neuron might have GABA receptors with pharmacological properties that differ from those we describe. Also, there might be pharmacological differences across species. For example, in salamander bipolar neurons, inhibition of $\mathrm{Ca}$ current by $\mathrm{GABA}$ is mediated by $\mathrm{GABA}_{\mathrm{B}}$ receptors that are sensitive to baclofen (Maguire et al., 1989), and in rat bipolar cells, both bicuculline-sensitive and bicuculline-resistant components of GABA-activated $\mathrm{Cl}$ conductance have been reported (Feigenspan et al., 1993). Nevertheless, negative feedback from amacrine cells to the synaptic terminals of bipolar cells is likely 
to be a universal feature of retinal signal processing, and the functional properties of the GABA receptors mediating the feedback are likely to be similar even if pharmacological details vary.

\section{Comparison of $\mathrm{Cl}$ conductance with $\rho_{1} G A B A$-receptor subunit}

The bicuculline-resistant $\mathrm{Cl}$ conductance activated by GABA in synaptic terminals of bipolar neurons is similar in a number of ways to the GABA-activated $\mathrm{Cl}$ conductance expressed in oocytes after injection of mRNA for the retina-specific subunit $\rho_{1}$ (Shimada et al., 1992). Both conductances are activated by muscimol, both have relatively high sensitivity to GABA $\left(K_{1 / 2}\right.$ $=0.9 \mu \mathrm{M}$ for $\rho_{1} ; K_{1 / 2}=3 \mu \mathrm{M}$ for bipolar cells), and both are blocked by picrotoxin but not by bicuculline. Desensitization has not been specifically studied for $\rho_{1}$ receptors, and the drug applications in our experiments were not sufficiently rapid to allow resolution of a rapid component of desensitization; however, published records for oocytes and our own GABA responses in bipolar cells (e.g., Figs. 2, 3, 7) show little evidence of slow desensitization, at least for moderate doses of agonist. These similarities suggest that the GABA-activated $\mathrm{Cl}$ conductance in bipolar-cell terminals involves a GABA receptor that is homologous to the $\rho_{1}$ subtype. These properties are somewhat different from the recently reported bicuculline-insensitive component of GABA responses in rat bipolar neurons (Feigenspan et al., 1993), which was found to be insensitive to picrotoxin, as well as bicuculline.

\section{Implications for retinal signal processing}

Based on the large synaptic terminal and the overall morphology, the bipolar neurons used in our experiments are likely to be type Mb1 cells (Ishida et al., 1980; Yazulla et al., 1987), which are a class of ON-type bipolar neuron. ON-type bipolar cells give sustained depolarizing responses to maintained increases in illumination (Werblin and Dowling, 1969; Kaneko, 1970). These cells are then thought to release glutamate (Ehinger et al., 1988; Marc et al., 1990) onto third-order amacrine and ganglion cells, producing excitation upon illumination. It has been suggested, therefore, that the GABAergic synapses from amacrine cells onto the bipolar-cell synaptic terminal constitute a negative feedback that opposes the light response and helps to convert sustained depolarizing responses in photoreceptors into transient responses in ganglion cells. As demonstrated in the fura-2 experiments, this negative feedback is highly effective, and the bicuculline-resistant $\mathrm{Cl}$ conductance is able to eliminate increases in $[\mathrm{Ca}]_{i}$ in the terminal in response to high $[\mathrm{K}]_{o}$. It should be pointed out that this inhibition by GABA is maintained even during prolonged applications (e.g., Fig. 5); that is, the response to moderate doses of GABA docs not slowly dcsensitize. Functionally, this may be important in a circuit consisting of nonspiking interneurons that show sustained responses during changes in illumination. This resistance to slow desensitization may be one reason the novel type of $\mathrm{GABA}_{\mathrm{A}}$ receptor is expressed in bipolar neurons.

In addition to the GABA-activated $\mathrm{Cl}$ conductance, we and Maguire et al. (1989) have shown that GABA also inhibits Ca current in bipolar-cell synaptic terminals. Given the potency of the $\mathrm{Cl}$ conductance in abolishing $\mathrm{Ca}$ influx into the terminal (see Figs. 5-7), the utility of this second effect of GABA may not seem obvious. However, as pointed out by Heidelberger and Matthews (1991), inhibition via $\mathrm{Cl}$ conductance is an inherently global mechanism because it works by clamping the membrane potential of the terminal as a whole; inhibition of Ca current via G-proteins might provide a means for GABA released at a particular feedback synapse to locally affect release from the bipolar-cell terminal, limited by the diffusion distance of the putative second messenger within the terminal. An alternative view is that the inhibition of Ca current per se is not the principal function of the $\mathrm{GABA}_{\mathrm{B}}$-like mechanism. Rather, by shifting the voltage range of activation of $\mathrm{Ca}$ current toward more positive potentials in ON-type bipolar cells (see Fig. 10), $\mathrm{G} \Lambda \mathrm{B} \Lambda$ would adjust the operating range of the Ca current such that the current would be most sensitive to voltage changes at the more depolarized level attained during steady background illumination. From this viewpoint, adaptation to steady illumination may be the principal functional consequence of activating the $\mathrm{GABA}_{\mathrm{B}}$-like receptors of bipolar-cell synaptic terminals.

\section{References}

Andrade R, Malenka RC, Nicoll RA (1986) A G protein couples serotonin and $\mathrm{GABA}_{B}$ receptors to the same channels in hippocampus. Science 234:1261-1265.

Ayoub GS, Matthews G (1991) Conformational specificity of GABA

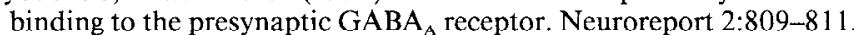

Barnes S, Bui Q (1991) Modulation of calcium-activated chloride current via $\mathrm{pH}$-induced changes of calcium channel properties in cone photoreceptors. J Neurosci 1 1:4015-4023.

Bley KR, Tsien RW (1990) Inhibition of $\mathrm{Ca}^{2+}$ and $\mathrm{K}^{+}$channels in sympathetic neurons by neuropeptides and other ganglionic transmilters. Neuron 2:379-391.

Bormann J, Clapham DE (1985) $\gamma$-Aminobutyric acid receptor channels in adrenal chromaffin cells: a patch-clamp study. Proc Natl Acad Sci USA 82:2168-2172.

Bormann J, Kettenmann HH (1988) Patch-clamp study of $\gamma$-aminobutyric acid receptor $\mathrm{Cl}^{-}$channels in cultured astrocytes. Proc Natl Acad Sci USA 85:9336-9340.

Bowery NG, Hill DR, Hudson AL, Doble A, Middlemiss DN, Shaw J, Turnhull M (1980) (-)Baclofen decreases neurotransmitter release in the mammalian CNS by an action at a novel GABA receptor. Nature 283:92-94.

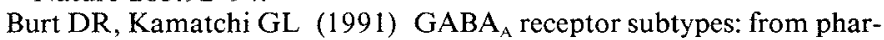
macology to molecular biology. FASEB J 5:2916-2923.

Curtis DR, Duggan AW, Felix D, Johnston GAR (1970) GABA, bicuculline and central inhibition. Nature 226:1222-1224.

Cutting GR, Lu L, O'Hara BF, Kasch LM, Montrose-Rafizader C, Donovan DM, Shimada S, Antonarakis SE, Guggino WB, Uhl GR, Kazazian $\mathrm{HH}$ Jr (1991) Cloning of the $\gamma$-aminobutyric acid (GABA) $\rho_{1}$ cDNA: a GABA receptor subunit highly expressed in the retina. Proc Natl Acad Sci USA 88:2673-2677.

Dolphin AC (1990) G protein modulation of calcium currents in neurons. Annu Rev Physiol 52:243-255.

Dolphin AC, Scott RH (1987) Calcium channel currents and their inhibition by (-)-baclofen in rat sensory neurones: modulation by guanine nucleotides. J Physiol (Lond) 386:1-17.

Drew CA, Johnston GAR, Weatherby RP (1984) Bicuculline insensitive GABA receptors: studies on the binding of $(-)$-baclofen to rat cerebellar membranes. Neurosci Lett 52:317-321.

Eckstein F, Cassel D, Levkowitz H, Lowe M, Selinger Z (1979) Guanosine 5'-O-(2-thiodiphosphate): an inhibitor of adenylate cyclase stimulation by guanine nucleotides and fluoride ions. J Biol Chem 254:9829-9834.

Ehinger B, Ottersen OP, Storm-Mathisen J, Dowling JE (1988) Bipolar cells in the turtle retina are strongly immunoreactive for glutamate. Proc Natl Acad Sci USA 85:8321-8325.

Feigenspan A, Wässle H, Bormann J (1993) Pharmacology of GABA receptor $\mathrm{Cl}^{-}$channels in rat retinal bipolar cells. Nature 361:159162.

Gähwiler $\mathrm{BH}$, Brown DA (1985) $\mathrm{GABA}_{\mathrm{B}}$-receptor-activated $\mathrm{K}^{+}$current in voltage-clamped $\mathrm{CA}_{3}$ pyramidal cells in hippocampal cultures. Proc Natl Acad Sci USA 82:1558-1562.

Heidelberger R, Matthews G (1991) Inhibition of calcium influx and 
calcium current by $\gamma$-aminobutyric acid in single synaptic terminals Proc Natl Acad Sci USA 88:7135-7139.

Heidelberger R, Matthews G (1992) Calcium influx and calcium current in single synaptic terminals of goldfish retinal bipolar neurons. J Physiol (Lond) 447:235-256.

Holz GG IV, Rane SG, Dunlap K (1986) GTP-binding proteins mediate transmitter inhibition of voltage-dependent calcium channels. Nature 319:670-672.

Ishida AT, Stell WK, Lightfoot DO (1980) Rod and cone inputs to bipolar cells in goldfish retina. J Comp Neurol 191:315-335.

Johnston GAR, Curtis DR, Beart PM, Game CJA, McCulloch RM, Twitchin B (1975) Cis- and trans-4-aminocrotonic acid as GABA analogues of restricted conformation. J Neurochem 24:157-160.

Kaneko A (1970) Physiological and morphological identification of horizontal, bipolar and amacrine cells in goldfish retina. I Physiol (Lond) 207:623-633.

Kerr DI, Ong J, Johnston GAR, Abbenante J, Prager RH (1989) Antagonism at $\mathrm{GABA}_{\mathrm{B}}$ receptors by saclofen and related sulphonic analogues of baclofen and GABA. Neurosci Lett 107:239-244.

Levitan ES, Schofield PR, Burt DR, Rhee LM, Wisden W, Köhler M, Fujita N, Rodriguez IIF, Stephenson A, Darlison MG, Barnard EA Seeburg PH (1988) Structural and functional basis for GABA $\mathrm{Ae}-$ ceptor heterogeneity. Nature 335:76-79.

Maguire G, Maple B, Lukasiewicz P, Werblin F (1989) $\gamma$-Aminobutyrate type $B$ receptor modulation of L-type calcium channel current at bipolar cell terminals in the retina of the tiger salamander. Proc Natl Acad Sci USA 86:10144-10147.

Marc RE, Lam DMK (1981) Glycinergic pathways in the goldfish retina. J Neurosci 1:152-165.

Marc RE, Liu W-LS, Kalloniatis M, Raiguel SF, Van Haesendonck E (1990) Patterns of glutamate immunoreactivity in the goldfish retina. J Neurosci 10:4006-4034.

Marshak DW (1992) Peptidergic neurons of teleost retinas. Vis Neurosci 8:137-144.

Matthews G, Ayoub GS, Heidelberger R (1991) Inhibition of presynaptic calcium current via $\mathrm{GABA}_{\subset}$ receptors. Soc Neurosci Abstr 17: 900.

Qian H, Dowling JE (1993) Novel GABA responses from rod-driven retinal horizontal cells. Nature 361:162-164.
Rodbell M (1980) The role of hormone receptors and GTP-regulatory proteins in membrane transduction. Nature 284:17-22.

Saito T, Kujiraoka T, Yonaha T (1983) Connections between photoreceptors and horseradish peroxidase-injected bipolar cells in the carp retina. Vision Res 23:353-362.

Schofield PR, Darlison MG, Fujita N, Burt DR, Stephenson FA, Rodrigue $\angle$ H, Rhee LM, Ramachandran J, Reale V, Glencorse TA, Seeburg PH, Barnard EA (1987) Sequence and functional expression of the $\mathrm{GABA}_{\mathrm{A}}$ receptor shows a ligand-gated receptor super-family. Nature 328:221-227.

Sherry DM, Yazulla S (1993) Goldfish bipolar cells and axon terminal patterns: a Golgi study. J Comp Neurol 329:188-200.

Shimada S, Cutting G, Uhl GR (1992) $\gamma$-Aminobutyric acid A or C receptor? $\gamma$-Aminobutyric acid $\rho_{1}$ receptor RNA induces bicuculline-, barturate-, and benzodiazepine-insensitive $\gamma$-aminobutyric acid responses in Xenopus oocytes. Mol Pharmacol 41:683-687.

Sigel E, Baur R, Trube G, Möhler H, Malherbe P (1990) The effect of subunit composition of rat brain $\mathrm{GABA}_{\mathrm{A}}$ receptors on channel function. Neuron 5:703-711.

Sigel E, Baur R, Kellenberger S, Malherbe P (1992) Point mutations affecting antagonist affinity and agonist dependent gating of $\mathrm{GABA}_{4}$ receptor channels. EMBO J 11:2017-2023.

Tachibana M, Kaneko A (1987) $\gamma$-Aminobutyric acid exerts a local inhibitory action on the axon terminal of bipolar cells: evidence for negative feedback from amacrine cells. Proc Natl Acad Sci USA 84: 3501-3505.

Werblin FS, Dowling JE (1969) Organization of the retina of the mudpuppy, Necturus maculosus. II. Intracellular recording. J Neurophysiol 32:339-355.

Woodward RM, Polenzani L, Miledi R (1992) Characterization of bicuculline/baclofen-insensitive $\gamma$-aminobutyric acid receptors expressed in Xenopus oocytes. I. Effects of $\mathrm{Cl}^{-}$channel inhibitors. Mol Pharmacol 42:165-173

Yazulla S (1986) GABAergic mechanisms in the retina. In: Progress in retinal research, Vol 5 (Osborne $\mathrm{N}$, Chader J, eds). New York: Pergamon.

Yazulla S, Studholme KM, Wu J-Y (1987) GABAergic input to the synaptic terminals of $\mathrm{Mb}-1$ bipolar cells in the goldfish retina. Brain Res 411:400-405. 